Review

\title{
Current Progress in Gene Delivery Technology Based on Chemical Methods and Nano-carriers
}

\author{
Lian Jin ${ }^{1, *}$, Xin Zeng ${ }^{2,}$, Ming Liu ${ }^{1}$, Yan Deng ${ }^{1,3}$, and Nongyue He $\mathrm{H}^{1,3}{ }^{\llbracket}$ \\ 1. State Key Laboratory of Bioelectronics, School of Biological Science and Medical Engineering, Southeast University, Nanjing 210096, \\ China \\ 2. Nanjing Maternal and Child Health Medical Institute, Nanjing Maternal and Child Health Hospital Affiliated of Nanjing Medical Uni- \\ versity, Nanjing 210029, China \\ 3. Economical Forest Cultivation and Utilization of 2011 Collaborative Innovation Center in Hunan Province, Hunan Key Laboratory of \\ Green Packaging and Biomedical Nanotechnology, Hunan University of Technology, Zhuzhou 412007, China \\ * These two authors contribute to this paper equally.
}

$\triangle$ Corresponding author: Nongyue He PhD, Sipailou No.2, Southeast University, Nanjing, 210096, China. Tel: +86-25-83790885, Fax: +86-25-83790885. email: nyhe1958@163.com.

( ) Ivyspring International Publisher. This is an open-access article distributed under the terms of the Creative Commons License (http://creativecommons.org/ licenses/by-nc-nd/3.0/). Reproduction is permitted for personal, noncommercial use, provided that the article is in whole, unmodified, and properly cited.

Received: 2013.06.15; Accepted: 2013.11.16; Published: 2014.01.15

\begin{abstract}
Gene transfer methods are promising in the field of gene therapy. Current methods for gene transfer include three major groups: viral, physical and chemical methods. This review mainly summarizes development of several types of chemical methods for gene transfer in vitro and in vivo by means of nano-carriers like; calcium phosphates, lipids, and cationic polymers including chitosan, polyethylenimine, polyamidoamine dendrimers, and poly(lactide-co-glycolide). This review also briefly introduces applications of these chemical methods for gene delivery.
\end{abstract}

Key words: Non-viral; Gene delivery; Vectors; Chemical Methods.

\section{Introduction}

A variety of genetic mutations, which alter cellular proliferation, angiogenesis, metastasis, and tumor immunogenicity result in human cancer, which has become one of the biggest threats to human life [1]. Despite increasing understanding of the molecular mechanism of cancers $[2,3]$, many malignancies remain resistant to established traditional treatments $[4,5]$. However, the definition of tumor-associated genetic mutations has heightened interest in cancer treatment as the target for gene therapy $[6,7]$.

The therapeutic expectations of gene therapy are considerable because of its significant potential for the treatment of inherited and acquired life threatening diseases caused by genetic deficiencies and abnormalities, such as cancer, acquired immune deficiency syndrome (AIDS), cardiovascular diseases, and certain autoimmune disorders. Gene transfer, or trans- fection, is a fundamental technique in molecular biology used to manipulate cells or study gene function and protein expression in vitro. When gene transfer is used in disease treatments, it is aimed at curbing genetic diseases by introducing genes coding for functional proteins to cells so as to normalize the cells and even organs. Gene transfer is not only used to treat genetic diseases, but also to produce large quantities of secreted proteins for direct therapeutic application or vaccines production. As is well known, it is difficult for nucleic acids to diffuse directly through plasma membrane due to their size and/or their physicochemical properties, for instance, hydrophilicity. Various strategies for the transfer of nucleic acids, especially genes, have thus been developed [8-10]. The ideal gene delivery and transfection systems should have high transfection efficiency, low toxicity 
to the cells and single cell specificity, while also is able to simultaneously treat heterogeneous systems with many different cells.

Current gene transfection systems contain three major groups: viral (transduction), physical (direct micro injection) and chemical methods. Initially, the gene transfer technique was envisioned to transform cells utilizing various viral vectors, as listed in Table 1, by inserting a functional gene into a nonspecific site within the genome. They are therefore the most advanced in development due to their efficiency and specificity in entering cells and expressing the genes carried in the modified viral genome using the cell's own biosynthetic machinery, particularly in vivo [22]. Unfortunately, well-known adverse effects were observed while using this system, such as immunogenicity, difficulties in handling and large-scale production, and limited length of the genes. Potential and real risks were observed in a clinical trial of an HIV vaccine developed from three weakened adenoviruses by Merck [23]. The failure to protect participants from HIV was suspected to associate with the vector itself or/and the pre-existing adenoviruse immunity of the participants, which have been the obstacle on the road from lab research to clinical use [24]. Physical methods for gene transfer (Figure 1) include biolistics, jet injection, ultrasound and so forth [25-29]. These methods have been developed quickly because such methods can directly penetrate genes into cells by stimulations of electric impulses, fine needle puncture or high-pressure gas, which may bypass some of the side effects linked to viral or biochemical approaches, such as limitation of the gene length that can be carried by the physical vectors. Physical methods medi- ate the direct penetration into the cytosol of both small and large nucleic acid molecules, as well as any other non-permeable molecule. Moreover, these physical systems are effective for single or multiple target cells at an intended location and carry little risk of dispersion of transfection reagents. However, they also present several drawbacks. On one hand, it is difficult for the genes to be transported to the nucleus because of little access in passing through the membrane or enzymatic digestion of the naked DNA or RNA, which results in the low transfection efficiency and limits its clinical application. On the other hand, they present damage to cells, difficulty in large-scale manipulation, labor-intensive protocols and/or the necessity of costly instruments [30].



Fig. I. Primary physical methods for gene delivery.

Table I. Viral systems for gene delivery.

\begin{tabular}{|c|c|c|c|}
\hline Transfection systems & Merits & Defects & References \\
\hline Adenoviruses vectors & $\begin{array}{l}\text { Large transgene capacity (up to } 38 \mathrm{~kb} \text { ), low } \\
\text { host specificity }\end{array}$ & $\begin{array}{l}\text { Tend to yield natural and acute immunologic } \\
\text { responses, short-term gene expression }\end{array}$ & 11,12 \\
\hline $\begin{array}{l}\text { Adeno-associated } \\
\text { vectors }\end{array}$ & $\begin{array}{l}\text { Safety, ability to integrate into a specific site on } \\
\text { chromosome } 19 \text { with no noticeable effects }\end{array}$ & $\begin{array}{l}\text { complicated process of vector production and } \\
\text { the limited transgene capacity (up to } 4.8 \mathrm{~kb} \text { ) }\end{array}$ & 13,14 \\
\hline Retroviral vectors & $\begin{array}{l}\text { Ability to transfect dividing cells, } \\
\text { suitable for in situ treatment, transgene capac- } \\
\text { ity of } 8 \mathrm{~kb}\end{array}$ & $\begin{array}{l}\text { low efficiency in vivo, immunogenic problems, } \\
\text { the inability to transfect the non-dividing cells } \\
\text { and the risk of insertion }\end{array}$ & 15,16 \\
\hline Lentivirus vectors & $\begin{array}{l}\text { High-efficiency infection of dividing and } \\
\text { non-dividing cells, long-term stable expres- } \\
\text { sion, low immunogenicity, transgene capacity } \\
\text { of } 8 \mathrm{~kb}\end{array}$ & $\begin{array}{l}\text { Difficult design and construction, concerns of } \\
\text { biosafety }\end{array}$ & 17,18 \\
\hline Herpes simplex virus vectors & $\begin{array}{l}\text { transgene capacity of up to } 150 \mathrm{~kb} \text {, neu- } \\
\text { ronotropic features }\end{array}$ & Difficulty to keep virus action under control & 19,20 \\
\hline Poxvirus vectors & $\begin{array}{l}\text { high stable insertion capacity (more than } 25 \\
\text { KB), simple construction, high expression } \\
\text { levels }\end{array}$ & $\begin{array}{l}\text { complex structure and biology, risk of cyto- } \\
\text { pathic effects }\end{array}$ & 21 \\
\hline
\end{tabular}


Table 2. Detailed information and cell types (in nine cell lines) with relatively higher luciferase gene transfection efficiency without fetal calf serum of six commercially available transfection reagents.

\begin{tabular}{|c|c|c|c|}
\hline Transfection reagent & Product origin & Based material & $\begin{array}{l}\text { Cell types with relatively higher transfection effi- } \\
\text { ciency }\end{array}$ \\
\hline Arrest-In & Open Biosystems, USA & Lipid-polymer & PT-30, HeLa, HepG2, 4T1, HCT116 \\
\hline ExpressFect & Denville, USA & Cationic polymer & HeLa, primary epidermal keratinocytes \\
\hline FuGENE HD & Roche, Switzerland & non-liposomal lipid & $\begin{array}{l}\text { MC3T3-E1, PT-30, C3H10T1/2, C2C12, Hep G2, 4T1, } \\
\text { HCT116 }\end{array}$ \\
\hline jetPEI & Polyplus-transfection, USA & linear PEI & $\begin{array}{l}\text { MC3T3-E1, MCF-7, C2C12, primary epidermal } \\
\text { keratinocytes }\end{array}$ \\
\hline Lipofectamine 2000 & Invitrogen, USA & cationic lipid & C3H10T1/2, MCF-7 \\
\hline SuperFect & Qiagen, USA & activated-dendrimer & \\
\hline
\end{tabular}

Although both viral systems and physical methods have drawn much attention of the researchers, they suffer from a number of drawbacks as described above. To overcome these drawbacks, a variety of chemical transfection systems, such as calcium phosphates, lipids, and cationic polymers including polyamidoamine dendrimers and polyethylenimine (PEI), etc, have been developed since late 1960s [31-32]. Chemical gene delivery systems were recognized as an alternative to viral gene vectors for their potential in avoiding some problems associated with the viral systems [33]. Great efforts have been made to increase the gene transfer efficiency and to minimize toxicity of these chemical transfection reagents by tuning their molecular structures and other features including size, surface potential and/or by combining them with other bio-functional molecules [32]. Currently, a variety of synthetic transfection reagents have been commercialized for in vitro gene transfer and both their detailed information and the comparison results of transfection efficiency are listed in Table 2 [34].

One of the most important reasons why these materials such as lipids and polymers can be used as the vectors for gene delivery is that they can interact with plasmid DNA (pDNA) to form nano-sized complexes, which is the premise to pass through the cell membrane. With the development of nanomaterials, nano-sized lipids and polymers have shown great potential as non-viral vectors for gene delivery.

Currently, both gene therapy and nanotechnology are controversial topics which have and will get much skepticism from both the general public and researchers for their significant safety problems. Nevertheless, considerable achievements in clinical use have already been made in both gene therapy and technology through the efforts of researchers [35, 36]. Moreover, the fastly developing nanotechnology and theranostics provide the powerful support for the development of the nanocarrier-based gene transfer methods [37]. Though there will be a lot of difficulties to resolve, they will be widely used with numerous research and rigorous administration, just like the genetically modified foods, which have be eventually admitted by FDA (U.S. Food and Drug Administration) and widely used in the world.

Herein, we mainly summarize several types of chemical transfection methods based on nanocarriers, which include calcium phosphates, lipids, and cationic polymers like chitosan, PEI, polyamidoamine dendrimers, poly (lactide-co-glycolide) and so on. On one hand, we discuss the mechanisms underlying these approaches as well as their achievements and, on the other hand, we compare their relative advantages and potential therapeutic applications in research, preclinical and clinical medicine.

\section{Calcium phosphate precipitation}

The systematic research on calcium phosphate gene transfer system was originally developed by Graham and Vander Eb [38]. In 1990, Orrantia explored the intracellular distribution of DNA internalized through calcium phosphate precipitation and proposed a new pathway in which exogenous DNA molecules may be transferred directly by intermediary vesicles from the endocytic-lysosomal compartment to the nucleus [39]. Since then, the calcium phosphate system has been widely used as an easy-to-use, cost-effective and highly safe gene transfer technique [40-41]. The conventional calcium phosphate gene transfer system is produced by particulate calcium phosphate co-precipitated with DNA. DNA-calcium phosphate co-precipitates arise spontaneously in supersaturated solutions. However, highly effective precipitates for transfection purposes can be generated only under very strict physic-co-chemical conditions because concentrations of calcium, phosphate and DNA as well as temperature and reaction time affect the formation of DNA-hydroxyapatite particles in a profound way. Most importantly, transfection efficiency and expression levels in both transient and stable transfections are influenced by those conditions referred above [42-43]. Other critical disadvantages of the calcium 
phosphate gene transfer system are insufficient efficiency and poor reproducibility compared with other non-viral carriers [44-45].

To get rid of these disadvantages, a lot of new methods based on the calcium-phosphate-DNA precipitation have been reported. First of all, nano-sized materials have drawn increased attention because of their intrinsic features based on the nanoscale size. Cao et al. developed calcium phosphate nanocomposite particles encapsulating plasmid DNA (CaP-pDNA), whose transfection efficiency was significantly higher than that of standard calcium phosphate transfection [40]. Elangovan et al. prepared nano-sized calcium phosphate particles, which displayed higher levels of biocompatibility and transfection efficiency in vitro [46]. Furthermore, there have been some optimizations of the fabrication process. Alireza et al. developed a new approach to prepare calcium phosphate nanoparticles through simulated body fluid (CaP-SBF), which indicated considerably high transfection efficiency in vitro for CaP-SBF/DNA complexes than those made in water [47].

In conclusion, the calcium phosphate co-precipitation method is an attractive option for their biocompatibility, biodegradability, ease of handling and capacity to adsorb pDNA. Nevertheless, there exists large space to make efforts to improve the transfection efficiency by developing new synthesis approach or combining calcium phosphate nanoparticles with other materials or methods [48].

\section{Lipids}

Among the non-viral vectors, liposomes based on cationic lipids are by far the most common gene delivery systems and have been the subject of considerable interests as non-viral delivery vectors [49-50]. Liposomes are synthetic lipid spheres composed by fatty acid on polymers with one or more bilayered membrane structure surrounding an aqueous core that can be used to encapsulate small molecules (Figure 2A, 2B). The direct complex formation of cationic lipids with pDNA results in the self-assembly of liposomes [51-52]. Several parameters, which influence the lipoplex formation efficacy, such as preparation procedure, mixing ratio, pDNA concentration, size of the applied cationic liposomes and ionic strength of the buffer were investigated [53].

As known, liposomes have the distinct advantages of being both nontoxic and biodegradable because they are composed of naturally occurring substances. Liposomes have been shown to provide stable encapsulation for various molecules like gene, which can protect DNA against enzymatic degradation as well as facilitate cellular uptake and endosomal escape, leading to effective gene transfer. They have possessed not only the excellent biocompatibility and low immunogenicity, but also the ability to deliver large pieces of DNA with well defined physicochemical composition and ease of handling and preparation. Furthermore, they have potential to transfect all kinds of tissue and cell types [54-57]. An upsurge of global interest in developing efficient cationic lipids for gene delivery was therefore witnessed in recent years [58-60].

However, due to their positive charge, cationic liposomes may undergo non-specific interaction with negatively charged cellular components (such as serum protein and enzymes), which may result in reduction of cellular adhesion, hemolysis, and low transfection efficiency [61-62]. In addition, organic reagents such as ethylether and chloroform are involved in the preparation of liposomes, which may be harmful to both the cells and tissues.

In general, cationic liposomes are not good enough for effective gene therapy because of their potential cytotoxicity and low transfection efficiency [63-66]. Therefore, it is significantly important to develop novel nontoxic cationic systems with both effective gene transfection ability and good safety.

The cytotoxicity of cationic liposomes mainly results from their cationic nature and the linker group [67]. There are correspondingly two major kinds of methods in the component optimization to improve transfection efficiency and reduce cytotoxicity. Firstly, great attention has been paid to synthetic modifications with the positively charged headgroup. For example, heterocyclic ring such as imidazolium pyridinium and protonated polyamine groups were introduced into cationic liposomes to decrease the positive charge of the cationic head [68-73]. Secondly, modification with the linker functionalization group is a good option to improve the properties of liposomes for gene delivery. Cationic liposomes with ether linkers are too stable to be biodegraded, leading to higher toxicity despite their good transfection efficiency [74]. However, the ester or amide linkers are more biodegradable and always bring on less cytotoxicity in cultured cells. Moreover, the lipids with these two linkers are easier to degrade in the circulatory system [75]. Carbamate is a widely studied structure with ability to keep lipids stable in the circulatory system while it may decompose and release DNA after entering endosomes [76]. Thus, lipids with a carbamate linker may be rapidly degraded into small molecules with much lower toxicity and, therefore, several cationic lipids were designed with the participation of carbamates [77-78]. Besides, cationic liposomes conjugated with polyethylene glycol (PEG) and/or other molecules such as ligands and peptides (Figure 2C, 2D) has been a great improvement lead- 
ing to small particle sizes, controlled structures, regular morphology, and good stability [79].

To evaluate the potential of the lipid transfection reagents in the clinical application, many researchers have embarked on the transfection experiments in vivo with functional gene [80-81]. Nabel et al. have developed a protocol which relies upon the direct transmission of human HLA-B7 gene into established tumors in vivo, which can perform successful gene expression and show no apparent toxicity [81].

Above all, cationic nano-sized liposomes have been investigated widely for a long time both in vitro and in vivo. Their gene delivery efficiency can be improved by intergrating with varying auxiliary methods, such as the availability of light sources and highly sensitive detection technologies [82]. But the progress is not great enough and the transfection efficiency and cellular non-toxicity have not been qualified to effective gene delivery. In other words, it is a way full of difficulties and challenges for cationic liposomes to move from researches to clinical applications in order to contribute to gene therapy.

\section{Polymeric carriers}

Cationic polymers have shown promise as a safe, predictable, biodegradable and nontoxic alternative to viral gene therapy, relying on endocytosis of synthetic polymer-based carriers bio-conjugated to the targeted gene or other biological molecules [83-84]. Cationic polymer-based gene carriers (polyplexes) showed good biodegradability, low toxicity, triggered nucleic acid release, structural diversity and relatively higher transfection efficiency than liposomes [85-87], and the gene delivery process of polymers is described in Figure 3. Many kinds of polymers have therefore been investigated for gene delivery, such as chitosan, PEI, polylysine, polyamino ester and so on [88-92]. Cationic segments, organelle-escape units, and degradable fragments are essential to a polymer-based vehicle for gene delivery. The majority of these cationic segments are derived from polyamines, including polylysine, polyarginine, chitosan, polyethylenimine and polyamidoamine dendrimers. Not only do these cationic polyamines protect DNA from degradation, they can also promote the endocytosis of the carriers by endosomal membranes. Degradable fragments are necessary for the carriers to release the DNA once the complexes enter the cytoplasm. Furthermore, the organelle-escape units are one of the key elements influencing the transfection efficiency.
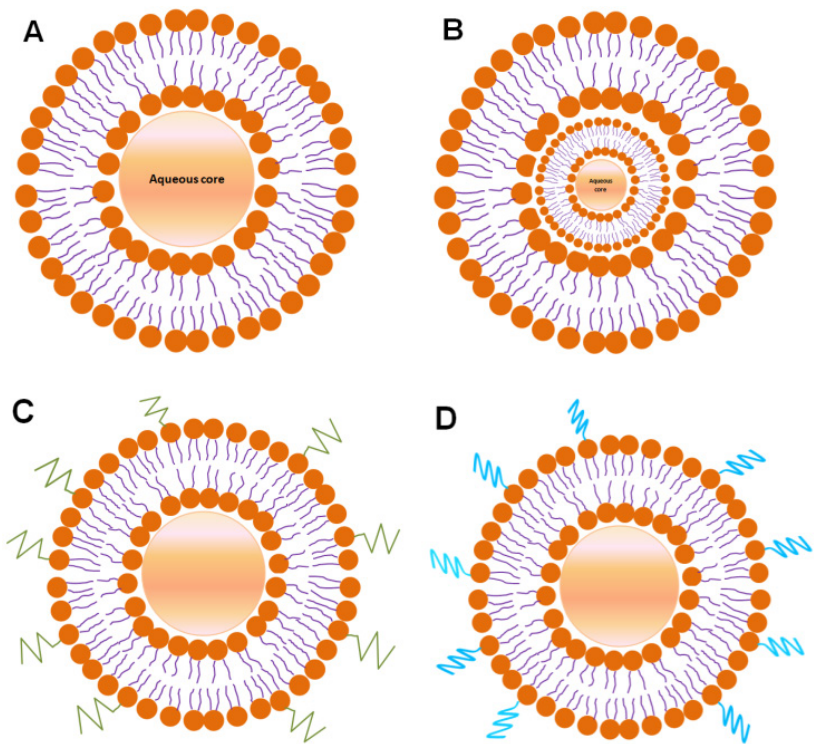

Fig.2. Schematic representation of the structure of liposomes.

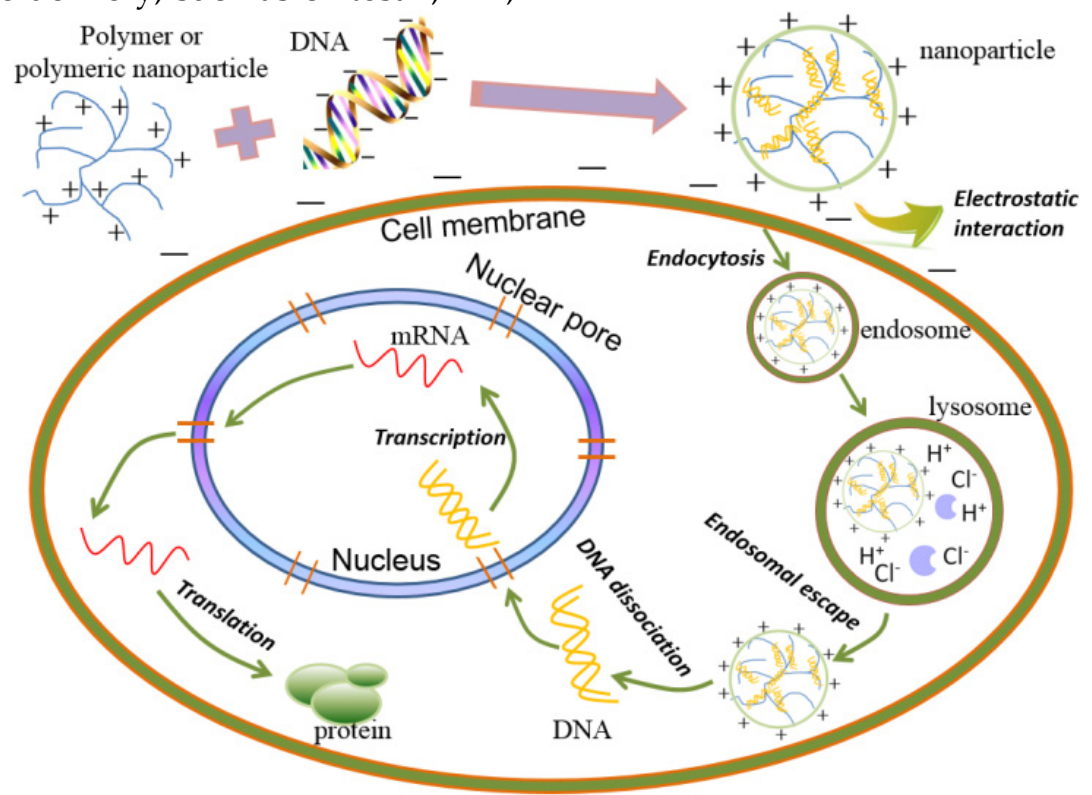

Fig.3. The schematic presentation of gene delivery process of polymers. 
However, there still exist numerous in vitro and in vivo barriers for polymer-based vehicles to achieve ideal transfection efficiency. For in vitro transfection, polymeric nanoparticles have no structure as magic as viruses to enter cells and just depend on the unpredictable endocytosis. Thus on one hand more detailed information about the endocytosis mechanism obtained by varying technical methods is needed to increase the entrance into the cells. On the other hand, the size, surface potential and N/P ratio (ratio of nitrogen of polymer to phosphate of DNA) were deeply investigated and some targeting groups like nuclear localization signal were integrated to the nanoparticles. Morover, the escape of nanoparticles from the organelle and DNA from the complexes is one of the key elements influencing the transfection efficiency. For example, particular interest was garnered by PEI mainly for its organelle-escape units. Another big problem for polymeric nanoparticles is the cytotoxicity, which results from poor biodegradability. So the degradable moieties have been incorporated into polymer, such as coating with human serum albumin, dextran, PEG and so forth. Out of these, the specific hurdle for transfection in vivo is that polymeric nanoparticles are foreign materials whose invasion will lead to the immune response by the body. The most effective solution is PEGylation, which help avoid the clearance of the reticuloendothelial system. Many researchers are dedicated to devising polymer-based vehicles for exogenous gene transfection in vitro and great efforts have been made for gene transfection in vivo.

\section{Chitosan}

During the past 20 years, a good many in vitro and in vivo studies focusing on gene therapy have been reported on chitosan for its outstanding biodegradability (Figure 4) [93-95]. Chitosan is an attractive polymer for gene delivery, showing excellent biocompatibility, admirable biodegradability, ecological safety, low toxicity, antimicrobial activity and low immunogenicity [96-100]. And chitosan with abundant amine and hydroxyl groups can be easily modified to enhance efficiency for gene transfer [101]. However, their application in gene delivery is limited for their insolubility under physiological $\mathrm{pH}$ condition, insufficient charge and low transfection efficiency [102-103].

The chitosan-DNA complexes are very easy to synthesize and are more effective in comparison with the commonly used polygalactosamine-DNA complexes. The stability of the complexes depends on several factors such as chitosan chain length and ratio of chitosan/DNA. The in vitro transfection efficiency was affected by factors such as the degree of deacety- lation (DDA), molecular weight (MW) of chitosan, nitrogen atoms $(\mathrm{N})$ in the chitosan/the phosphorus atoms $(\mathrm{P})$ in DNA $(\mathrm{N} / \mathrm{P})$ ratio, physicochemical properties of polyplexes, and so forth [104-107]. Considering these important factors, great efforts have been devoted to obtain higher transfection efficiency [107-109]. Taking the MW for example, investigation on the MW of the polymer revealed that on one hand high MW chitosan offered better nucleic acid complexation and stability but showed drawbacks such as aggregation and low solubility at neutral $\mathrm{pH}$ [110-112]. On the other hand, low MW chitosan allows for a more efficient intracellular release but low complexation [113]. Hence finding a balance between these opposing effects is important to obtain a chitosan carrier of optimal MW. To address the problem of insolubility under physiological $\mathrm{pH}$ condition, hydrophobic and hydrophilic modifications have been applied to obtain chitosan derivatives with favorable characteristics. Hydrophobic modifications, such as deoxycholic acid modification and thiolation, could reinforce cell binding, alleviate serum inhibition, protect the pDNA from enzymatic degradation, and facilitate pDNA internalization, which have been proven good for efficient gene transfer [114-117]. While a plenty of hydrophilic modifications, such as PEGylation and quaternization, were also introduced to enhance transfection efficiency due to increased water solubility at physiological $\mathrm{pH}$ and improved intracellular pDNA release [118-120]. The distinct benefits of hydrophobic and hydrophilic modifications have promoted the possibility of obtaining well-defined amphiphilic chitosan derivatives [121-122]. Nevertheless, certain factors acted differently when combined with various states of other factors. What is most important is therefore to find a fine balance between all the tunable influencing factors on chitosan to get ideal transfection efficiency [123-125].

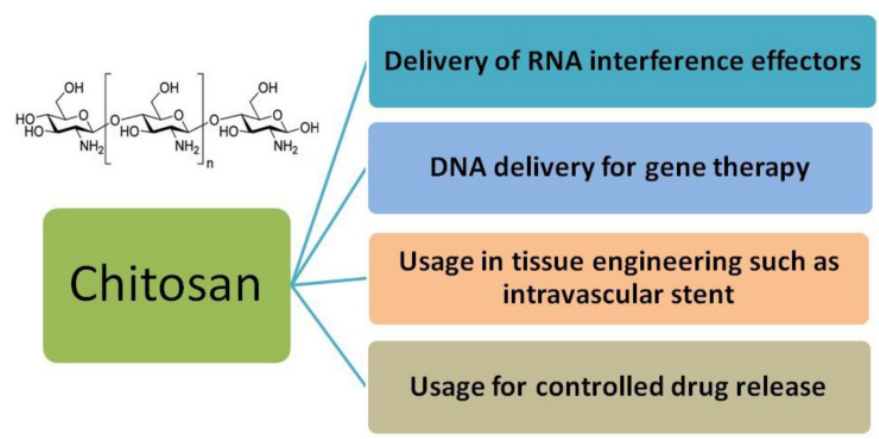

Fig.4. Primary applications of chitosan in biomedical fields. 
The modes of administration also significantly influence gene delivery efficiency and new methods have been reported [126-127]. Using a novel technique, Dai et al. studied the gene delivery by chitosan-DNA nanoparticles through retrograde intrabiliary infusion (RII), which proved a possible routine to achieve low-toxic, liver-targeted gene delivery [127].

Currently, the optimization of chitosan-based vectors for gene delivery includes two dominant points, the modification of chitosan itself and combination with other vectors [128]. Consequently, the former should be incorporated with the latter, which may be the development tendency of chitosan-based vectors [129]. Liu et al. synthesized amphiphilic chitosan-N-octyl-N-quatenary chitosan (OTMCS)-PEI which revealed lower cytotoxicity and the OTMCS-PEI/DNA complexes showed higher transfection efficiency in vitro and in vivo in comparison with PEI $25 \mathrm{kDa}$, the commercially available one [130].

\section{Polyethylenimine (PEI)}

Among various kinds of cationic polymers, PEI has been the most widely investigated because of not only its strong DNA condensation capacity and intrinsic endosomal activity, but also its unique buffering capacity called proton sponge effect (Figure 5). It facilitates the release of the gene into the cytoplasm through osmotic swelling and burst of endosomes [131-132]. Figure 6 shows two forms of PEI, linear PEI (IPEI) and branched PEI (bPEI). PEI nanoparticles have been prepared by two strategies that either by complexation of PEI with DNA to form nano-complexes [133] or use of cross-linkers to first form PEI nanoparticles followed by DNA loading onto it [134-135].

The transfection efficiency of PEI/pDNA polyplexes is associated with the N/P ratio [135-136]. PEI polyplexes of $\mathrm{N} / \mathrm{P}$ ratios higher than 3 contain an excess of free PEI which is supposed to contribute to the endosomal escape [137], which explains the usually enhanced transfection efficiency at higher $\mathrm{N} / \mathrm{P}$ ratios. The transfection efficiency of $\mathrm{PEI} / \mathrm{pDNA}$ complexes depends largely on the molecular weight (MW) of PEI. Commercially available PEI $25 \mathrm{kDa}$ has excellent transfection efficiency in comparison with low-molecular-weight PEI (LMW PEI) [138-140]. With its high cationic charge density, it can effectively condense DNA and form nanometer-sized particles capable of being endocytosed [141]. However, high-molecular-weight PEI (HMW PEI) $25 \mathrm{kDa}$ ), with efficient gene transfection in vitro, lacks degradable linkages (C-C or C-N bonds) and is too toxic for therapeutic applications, which contributes to an acute cytotoxicity due to cell membrane disruption followed by induction of apoptosis [142-143]. On the contrary, LMW PEIs possess low cytotoxicity as well as undesirable transfection efficiency [139, 144-146]. It is therefore a significant challenge to prepare PEI-based vectors with high transfection efficiency as well as low cytotoxicity [147-149]. Moreover, when it comes to in vivo transfection, PEI has the tendency to aggregate red blood cells, bind complement components, and is not easy to be broken down and excreted [150-151].

Fig.5. Schematic representation of proton sponge effect of PEI polymer.






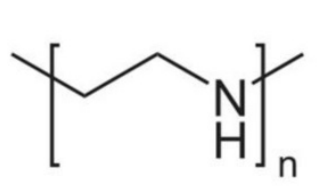

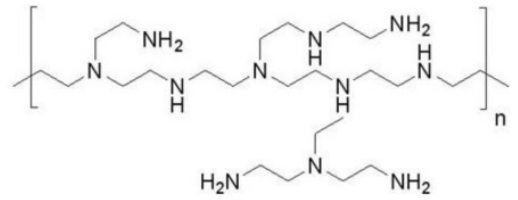

B
Fig.6. Two forms of PEl. (A) linear PEI, (B) branched PEI.

There are two primary ways to overcome these problems, modification of HMW PEIs to decrease the cytotoxicity and modification of LMW PEIs to improve the transfection efficiency. As for HMW PEIs, degradable linkers are used to conjugate PEI to yield polymers with sufficient amounts of amino groups. Lee et al. first introduced disulfide cross-linked PEI using dithiobis succinimidyl propionate and dimethyl-3,3'-0-dithiobispropionimidate as cross-linking agents, which showed apparently reduced cytotoxicity [152]. Breunig et al. have reported that several cell lines transfected with disulfide crosslinked IPEI has shown transfection efficiencies of over $60 \%$ under conditions that maintain a cell viability $>90 \%$ [153-154]. Studies of PEI crosslinked with other hydrolytically degradable groups have also been reported with efficiencies near or exceeding that of commercially available standards, as well as reduced cytotoxicity [155-162].

To improve the transfection efficiency of LMW PEIs, one of the main approaches is to incorporate hydrophobic moieties into LMW PEIs. In previous studies, some hydrophobic segments have been introduced into LMW PEIs, such as polycaprolactone, cholesterol, lipid and other hydrophobic substituents [163-169]. Those results indicated that transfection efficiency could be apparently improved after introducing hydrophobic chains into LMW PEIs, which might result from the unique properties of amphiphilic cationic polymers. The self-assembly of amphiphilic polymers could improve the local cationic density and then facilitate nucleic acid condensation. In addition, hydrophobic substituents were expected to enhance interactions with lipophilic cell membranes and facilitate the uptake of the complexes. After release of the nucleic acids, self-assemblies of amphiphilic polymers might be disassembled into unimers, leading to relatively low cytotoxicity [170]. In addition, disulfide cross-linked PEI-SSX and ester-cross-linked PEI derivatives based on different cross-linking agents and LMW PEI have also been investigated and exhibited higher gene transfection efficiency and lower cytotoxicity than PEI ( $25 \mathrm{kDa})$ in different types of cell lines [171-173]. Besides, the adjustment of particle size can also lead to effective gene transfer. Recently, it has been reported that copolymers obtained by the reaction between PCL diacrylate and LMW PEI show effective and stable DNA condensation with particle sizes less than $200 \mathrm{~nm}$ [174].

No matter HMW PEIs or LMW PEIs, intracellular release of DNA from the complexes is of the utmost importance for the transfection efficiency. In order to trigger intracellular release of therapeutic genes from cross-linked PEI, there are two promising methods, hydrolytic degradation and disulfide reduction. Disulfide cross-linked polymers were synthesized to stimulate the DNA release in the cytoplasm by intracellular reducing environment [175].

In conclusion, although PEI has been investigated widely in animals and humans for gene delivery in vitro and in vivo [176], there exist a lot of challenges such as the cytotoxicity, insufficient transfection efficiency and instability of the complexes in complicated physiological environments, which blocks their clinical applications. Many kinds of PEI derivatives have shown relatively lower cytotoxicity and higher transfection efficiency, nevertheless, it is really a long way to go before using them for clinical treatment. Generally, new vectors with well-marked reduced toxicity, improved transfection efficiency and better stability of the complexes in vivo, are of great importance. That is to say, great emphasis should be placed on the inner mechanism of toxicity, effective targeting of cells or organs, enhanced nuclear localization and how to pass through the barriers to cells or nuclei.

\section{Polyamidoamine Dendrimers}

Polyamidoamine (PAMAM) dendrimers are highly branched spherical polymers that are highly soluble in aqueous solution and have a unique surface of primary amino groups [177-179]. Moreover, PAMAM dendrimers are a class of macromolecules that are uniformly dispersed in comparison with many other kinds of polymers investigated recently [180-183]. They can be produced in large quantities and precisely synthesized over a range of molecular weights. The structure starts from a core molecule and grows through stepwise polymerization process. With each new layer or generation, the number of surface amine groups exactly increases, which have been used for the attachment of antibodies, contrast agents, and radio pharmaceuticals for applications in a number of different areas of biology and medicine [181, 182]. PAMAM dendrimers have therefore been extensively explored as non-viral gene carriers because of their unique characteristics, such as narrow molecular distribution, defined size and shape, high molecular uniformity and highly functionalized terminal surface [184-187]. They are nano-spherical, hyper-branched and mono-dispersive molecules which are suitable for gene delivery. 
Dendrimers have an increased ionic interaction with DNA and produce very stable and highly soluble DNA complexes [188]. However, there exist several problems to be solved. First, although PAMAM dendrimer-based gene transfection reagents such as $\mathrm{Su}-$ perfect and Priofect have already been commercially available, these products are more expensive than other cationic polymers and are based on high generation dendrimers, the synthesis of which is labor-consuming [189]. Second, the transfection efficiency of PAMAM dendrimers is generation-dependent. Low-generation PAMAM, such as G0-G3 show poor gene transfection efficiency and lower cytotoxicity, but high-generation PAMAM, such as G4-G8 exhibit slightly better gene transfection efficiency and higher cytotoxicity [190-192]. But ideal gene transfection reagents should have both high transfection efficiency and low cytotoxicity and thus plenty of efforts have been made to achieve it [193, 194]. On one hand, high generation PAMAM dendrimers were functionalized with different moieties as showed in Table 3. However, high transfection efficiency is usually accompanied with high cytotoxicity in these gene delivery systems. So the paradox between transfection efficiency and cytotoxicity makes it of crucial importance to break up the correlation between them for PAMAM dendrimer-based gene carriers in a near future [210]. A promising solution to this issue is to prepare highly efficient gene transfection reagents using low generation dendrimers. Liu et al. synthesized disulfide cross-linked low generation PAMAM dendrimers for gene delivery which showed higher transfection efficiency than G2 and G5 PAMAM dendrimers and comparable efficiency with bPEI $25 \mathrm{kDa}$ [192]. Uekama et al. developed cyclodextrin-modified low generation PAMAM dendrimers for DNA delivery [201-203, 211]. In their studies, relatively high gene transfection efficiency and low cytotoxicity of the cyclodextrin-dendrimer conjugates were achieved. On the other hand, hyper-branched PAMAM dendrimers and their modifications have been extensively investigated to increase pDNA binding [212-215]. An interesting option to obtain efficient gene delivery carriers is to increase dendrimer flexibility using a triethanolamine core. In this case the enhanced distance of the first generation branching points to the central amine leads to a more flexible dendrimer and thus increases pDNA binding [215]. Zeynep et al. prepared Jeffamine-cored PAMAM dendrimers (JCPDs) for gene delivery, which showed considerably improved transfection efficiency as the number of generation increased [216]. JCPD can therefore be considered as an efficient transfection reagent and can be effectively used for gene delivery applications, which is based on the finding that partially degraded PAMAM den- drimers show better flexibility and greater interaction with pDNA and perform successful transfer of pDNA [217]. Finally, the transfection efficiency of specific dendrimer varies between different types of cells, which is the common problem for all kinds of gene carriers and may be closely related with different structures of different cells [218].

Table 3. Functionalization of high generation PAMAM dendrimers to achieve higher transfection efficiency.

\begin{tabular}{lll}
\hline $\begin{array}{l}\text { Functionalization objec- } \\
\text { tive }\end{array}$ & $\begin{array}{l}\text { Functionalization moie- } \\
\text { ties }\end{array}$ & References \\
\hline $\begin{array}{l}\text { tailor the dendrimer } \\
\text { surface charge and } \\
\text { hydrophobicity }\end{array}$ & $\begin{array}{l}\text { aliphatic acid and amino } \\
\text { acids including arginine, } \\
\text { phenylalanine, lysine, }\end{array}$ \\
Specific targeting & $\begin{array}{l}\text { leucine and proline } \\
\text { targeting moieties such as } \\
\text { biotin, transferrin, folic } \\
\text { acid, mannose, lactose, } \\
\text { galactose, and peptides } \\
\text { guanidine and spermine }\end{array}$ \\
& $\begin{array}{l}\text { [199] } \\
\text { nanoparticles such as } \\
\text { gold nanoparticles and } \\
\text { carbon nanotubes }\end{array}$ \\
\hline
\end{tabular}

\section{Poly (lactide-co-glycolide)}

Poly (lactide-co-glycolide) (PLGA), as the name suggests, is composed of lactic and glycolic acids, which are linked together by ester linkages. The polymer degrades when the free carboxylic end groups form. The safety of PLGA-based nanoparticles in the clinic has been well established [219]. Incorporation of pDNA into PLGA particles protects pDNA from in vivo degradation, triggers the controlled release of the pDNA, and acts as a transfection vector for mammalian cells [220-223]. A PLGA based delivery system for pDNA has been widely studied and demonstrated effectively [224-232].

However, the low release rate of pDNA from conventional PLGA, negative charges which hinder DNA encapsulation and changes of pDNA structure induced by the acidic microenvironment of the PLGA particles made it difficult to perform ideal results [233-236]. Recently, a new delivery system incorporating CaP-pDNA co-precipitate into PLGA microparticles was explored and the CaP-pDNA PLGA micron delivery system has demonstrated a better pDNA loading efficiency and better protection of pDNA relative to PLGA based micron delivery system itself [237]. Unfortunately, there are some obvious drawbacks of this PLGA micron system, such as slow release of pDNA and consequently low transfection efficiency in vitro due to the large size of the carrier [226, 238-239]. Orrantia et al. traced ${ }^{32}$ P-marked DNA inside the cell and concluded that the particle size in 
nanoscale would help the protection of pDNA from degrading enzymes [240]. Loyter et al. has also emphasized the importance of the nano-scaled particle size after studying the intracellular transport of ${ }^{3} \mathrm{H}$-marked DNA [241]. And in some cell lines, only the nano-sized particles are taken up efficiently other than microparticles (e.g. Hepa1-6, HepG2, and KLN205) [242]. Those studies revealed the importance of the particle size in gene transfection efficiency.

Recently, Tang et al. reported a simple and reproducible method to prepare well-defined CaP-pDNA PLGA nanoparticles for the incorporation of pDNA, which will enhance pDNA encapsulation within the particle, provide an ideal release rate of pDNA, and increase transfection efficiency in vitro [243]. In another study, Shau et al. concluded that a one-step preparation of nanoparticles with PLGA pre-modified with PEI is better in requirements for DNA delivery compared with those prepared in a two-step process (preformed PLGA nanoparticles and subsequently coated with PEI) [244]. Zeng et al. indicated that nanoparticles fabricated with PLGA alone resulted in poor encapsulation of pDNA while chitosan-modified PLGA nanoparticles exhibited much higher loading efficiency than unmodified PLGA nanoparticles [245].

Generally, PLGA-based nanoparticles have already been widely investigated in drug delivery in vivo for its safety and used for clinical usage, but its application for ideal gene delivery remains a way filled with challenges and prospects.

\section{Other polymeric carriers}

As the polymers arouse more attention of the researchers, more and more new polymeric carriers have been developed for gene transfer. Some typical polymeric carriers are listed in Table 4 and at the same time many other polymeric carriers such as polypeptide and polyphosphoester have also been reported [246-250].

Poly-L-lysine (PLL) is a kind of natural and biocompatible polypeptide with excellent pDNA condensation capacity and one of the cationic polymers firstly used for gene delivery [251-252]. However, the high cytotoxicity and the low transfection efficiency of PLL severely limit its wide application in gene delivery [253-257].

Many attempts have been made to improve the gene delivery efficiency. For example, PEG was introduced to reduce the cytotoxicity [258], target ligands such as transferrin, folate, antibodies and basic fibroblast growth factor were tethered to promote complex cellular uptake [259-262], and histidine derivatives were grafted to improve the endosomal escape of the complexes [263]. Nevertheless, the applications of PLL are widely limited in comparison with other polymers like PEI, CS and PAMAM [264-265].

\section{Combination}

Chemical vectors for gene delivery based on only one kind of pure materials, such as lipid or chitosan, have not only their special advantages but also their intrinsic deficiencies which are difficult to resolve. To improve the transfection efficiency and reduce the cytotoxicity, many researchers have focused on combining two or more kinds of materials to enhance the transfection efficiency and at the same time avoiding the side effects to the cells [266]. Dendron-bearing lipids with PAMAM G1 designated as DL-G1-2C18 have been synthesized. In spite of less efficient cellular uptake of the lipoplexes, they generated free pDNA molecules in the cytosol more effectively than other lipoplexes did [267].

Table 4. Summary of polymeric carriers.

\begin{tabular}{|c|c|c|c|}
\hline Carriers & Main advantages & Main limitations & References \\
\hline Chitosan & $\begin{array}{l}\text { Good biocompatibility and biodegradability; low im- } \\
\text { munogenicity; low toxicity; antimicrobial activity; }\end{array}$ & $\begin{array}{l}\text { Low insolubility under physiological } \mathrm{pH} \text { con- } \\
\text { dition; low transfection efficiency; }\end{array}$ & $\begin{array}{l}{[94,95,98,100,104,} \\
105]\end{array}$ \\
\hline PEI & $\begin{array}{l}\text { Strong DNA condensation capacity; intrinsic endoso- } \\
\text { mal activity; unique buffering capacity; high transfec- } \\
\text { tion efficiency; }\end{array}$ & $\begin{array}{l}\text { Bad biodegradability; the contradiction be- } \\
\text { tween transfection efficiency and cytotoxicity; }\end{array}$ & $\begin{array}{l}{[135,138} \\
139,140 \\
142,143 \\
146]\end{array}$ \\
\hline PAMAM & $\begin{array}{l}\text { surface functionality; relatively high transfection effi- } \\
\text { ciency; uniform size distribution; lower cytotoxicity; }\end{array}$ & Low transfection efficiency; & $\begin{array}{l}{[177,179} \\
180,183 \\
186,187]\end{array}$ \\
\hline PLGA & Safety; good biodegradability; & $\begin{array}{l}\text { Low release rate and low encapsulation effi- } \\
\text { ciency of pDNA; acidic microenvironment } \\
\text { induced by it; }\end{array}$ & $\begin{array}{l}{[224,226,} \\
227,234 \\
235]\end{array}$ \\
\hline PLL & Excellent pDNA condensation capacity; & $\begin{array}{l}\text { Relatively high cytotoxicity; low transfection } \\
\text { efficiency; }\end{array}$ & {$[254,256]$} \\
\hline
\end{tabular}


Most importantly, the core-shell nanoparticles for gene delivery have been the hot topic in the past few years. Although calcium-phosphate precipitation has been used to deliver pDNA for decades, the method is typically characterized by low transfection efficiency relative to the other non-viral approaches, such as liposomes and polymers. Zhou et al. have developed a novel gene transfer vector comprising lipid-coated nano-calcium-phosphate (LNCP) that provides consistently efficient and satisfactory pDNA delivery [268]. It is based on core-shell nanoparticles comprising of a calcium-phosphate core and a cationic lipid shell. This method, in contrast to the solution precipitation methods used in the past, yields colloidally stable calcium-phosphate nanoparticles inside the cationic liposomes. The LNCP has shown great potential as a novel transfection agent for gene therapy. Jiang et al. have designed another cationic core-shell lipo-nanoparticle (DLCS-NP) by enveloping the plasmid-laden chitosan nanoparticle (CSNP) into a cationic lipid shell to achieve enhanced gene transfection efficiency for ocular eye-drop therapy [269]. The cellular uptake of DLCS-NP is up to 1.25-fold and 5-fold higher than that of CS-NP and lipid-coated chitosan nanoparticles (LCS-NP), respectively. Moreover, it is another promising direction for gene delivery to combine with advanced theranostic systems and a number of liposomes and polymeric carriers combined with approved therapeutics have entered clinical use or are under different stages of clinical application [270-274].

\section{Conclusion}

All the gene transfer methods (viral, physical or chemical) must overcome two major constraints: first, there is a need to carry the nucleic acids to the target cells without potential risks. Viruses are 'naturally' equipments with ability to recognize and locate defined target cells and are 'stealthy' with respect to the body defense mechanisms, such as the reticulo-endothelial system (RES). While chemical vectors should combine with other technologies or conjugate with targeting molecules to realize the specific location. The second constraint is the penetration of the nucleic acids into the cell through the plasma membrane. While viruses achieve this purpose using natural mechanisms, chemical vectors must perturb the plasma membrane (e.g. physical vectors) and/or internal vesicular membranes (e.g. the cationic lipids). In order to obtain an efficient vector system and achieve a high rate of cell transfection, these two conditions must be integrated in the development of an ideal genetic vector.

Consequently, deep investigation of the transfection process incluing the endocytose of nanocarri- ers and the release of DNA from the complexes is the prerequisite for gene delivery research in the future. Only with deep understanding of the mechanism can we suit our methods to the situation. To pay more attention to materials with excellent biodegradability and biocompability is an important alternative to get effective gene delivery nanocarriers in the near future. Further, functional moieties such as cell penetration peptides to the nanocarriers could be popular to improve the transfection efficiency and at the same time decrease the cytotoxicity. What's more, different gene delivery systems should be effectively combined to make best use of the advantages and bypass the disadvantages, which tend to be the main stream in gene delivery. Inorganic nanoparticles possess many advantages in gene transfection, e.g. they are not subject to microbial attack and exhibit good storage stability [275]. As a result of their small size, nanoparticles can penetrate the cell membrane and deliver drugs or biomolecules into living systems with moderate toxicity [276-277] or without any toxic effects on cells [278], depending on the concentration of nanoparticles used. There is a wide variety of nanoparticles and many of them have been tested in vitro and in some cases even in clinical trials, e.g. carbon nanotubes, chitosan nanoparticles, calcium phosphate nanoparticles and lipid nanoparticles [279-282]. In conclusion, it is not only a way full of challenges and difficulties, but also a way filled with hope and prospect in medical fields.

\section{Acknowledgments}

This research was financially supported by the National Key Program for Developing Basic Research of China (2010CB933903 and 2014CB744501), the NSFC (61271056 and 31201003), Hunan Science and Technology Projects (2012SK3105), Scientific Research Fund of Hunan Provincial Education Department (11A030), China Postdoctoral Science Foundation (20100471362, 2012M520980 and 2012M511660), Jiangsu Postdoctoral Science Foundation (1301093C), Open Research Fund by State Key Laboratory of Bioelectronics, Southeast University, China (2013G10) and Economical Forest Cultivation and Utilization of 2011 Collaborative Innovation Center in Hunan Province.

\section{Competing Interests}

The authors have declared that no competing interest exists.

\section{References}

1. Gupta A, Sharma A, von Boehmer L, Surace L, Knuth A, van den Broek M. Radiotherapy supports protective tumor-specific immunity. Oncoimmunology. 2012; 1(9): 1610-1611. 
2. Gajjar M, Candeias MM, Malbert-Colas L, Mazars A, Fujita J, Olivares-Illana $\mathrm{V}$, Fåhraeus R. The p53 mRNA-Mdm2 interaction controls Mdm2 nuclear trafficking and is required for p53 activation following DNA damage. Cancer Cell. 2012; 21(1): 25-35.

3. Moon EK, Son M, Jin YW, Park S, Lee WJ. Variations of Lung Cancer Risk from Asbestos Exposure: Impact on estimation of population attributable fraction. Ind Health. 2013; 51(1): 128-133.

4. Chang HJ, Ko HL, Lee CY, Wu RH, Yeh YW, Jiang JS, Kao SJ, Chi KH. Hypofractionated radiotherapy for primary or secondary oligometastatic lung cancer using Tomotherapy. Radiat Oncol. 2012; 7: 222.

5. Henson KE, McGale P, Taylor C, Darby SC. Radiation-related mortality from heart disease and lung cancer more than 20 years after radiotherapy for breast cancer. Br J Cancer. 2013; 108(1): 179-182.

6. Gill S, Kalos M. T cell-based gene therapy of cancer. Transl Res. 2013; 161(4): 365-379.

7. Song H, Song C, Wang H, et al. Suppression of hepatocarcinoma model in vitro and in vivo by ECRG2 delivery using adenoviral vector. Cancer Gene Ther. 2012; 19(12): 875-879.

8. Mannell H, Pircher J, Fochler F, Stampnik Y, Räthel T, Gleich B, Plank C, Mykhaylyk O, Dahmani C, Wörnle M, Ribeiro A, Pohl U, Krötz F. Site directed vascular gene delivery in vivo by ultrasonic destruction of magnetic nanoparticle coated microbubbles. Nanomedicine. 2012; 8(8): 1309-1318.

9. Iwashita S, Hiramatsu Y, Otani T, Amano C, Hirai M, Oie K, Yuba E, Kono K, Miyamoto M, Igarashi K. Polyamidoamine dendron-bearing lipid assemblies: Their morphologies and gene transfection ability. J Biomater Appl. 2012; 27(4): 445-456

10. Siu YS, Li L, Leung MF, Lee KL, Li P. Polyethylenimine-based amphiphilic core-shell nanoparticles: Study of gene delivery and intracellular trafficking. Biointerphases. 2012; 7(1-4): 16

11. Thrasher AJ, Gaspar HB, Baum C, Modlich U, Schambach A, Candotti F, Otsu M, Sorrentino B, Scobie L, Cameron E, Blyth K, Neil J, Abina $\mathrm{SH}$, Cavazzana-Calvo M, Fischer A. Gene therapy: X-SCID transgene leukaemologenicity. Nature. 2006; 443(7109): E5-E6.

12. Zhang Y, Gao Y, Speth RC, Jiang N, Mao Y, Sumners C, Li H. Adenoviral and adeno-associated viral vectors-mediated neuronal gene transfer to cardiovascular control regions of the rat brain. Int J Med Sci. 2013; 10(5): 607-616.

13. Teramato $\mathrm{S}$, Ishii $\mathrm{T}$, Matsuse $\mathrm{T}$. Crisis of adenoviruses in human gene therapy. Lancet. 2000; 355(9218): 1911-1912.

14. Okada H, lizuka T, Mochizuki H, Nihira T, Kamiya K, Inoshita A, Kasagi $\mathrm{H}$, Kasai M, Ikeda K. Gene transfer targeting mouse vestibule using adenovirus and adeno-associated virus vectors. Otol Neurotol. 2012; 33(4): 655-659.

15. Anson DS. The use of retroviral vectors for gene therapy-what are the risks? A review of retroviral pathogenesis and its relevance to retroviral vector-mediated gene delivery. Genet Vaccines Ther. 2004; 2(1): 9

16. Frederic D. Retroviral integration and human gene therapy. J Clin Invest. 2007; 117(8): 2083-2086.

17. Goss JR, Mata M, Goins WF, Wu HH, Glorioso JC, Fink DJ. Antinociceptive effect of a genomic herpes simplex virus-based vector expressing human proenkephalin in rat dorsal root ganglion. Gene Ther.2001; 8(7): 551-556.

18. Real G, Monteiro F, Burger C, Alves PM. Improvement of lentiviral transfer vectors using cis-acting regulatory elements for increased gene expression. Appl Microbiol Biotechnol. 2011; 91(6): 1581-91.

19. Lachmann RH, Efstathiou $\mathrm{S}$. The use of herpes simplex virus-based vectors for gene delivery to the nervous system. Mol Med Today. 1997; 3(9): 404-411.

20. Liu S, Dai M, You L, Zhao Y. Advance in herpes simplex viruses for cancer therapy. Sci China Life Sci. 2013; 56(4): 298-305.

21. Moss B. Reflections on the early development of poxvirus vectors. Vaccine. 2013; 31(39): 4220-4222

22. Mulligan RC. The basic science of gene therapy. Science. 1993; 260: 926-932.

23. [No authors listed]. HIV vaccine failure prompts Merck to halt trial. Nature. 2007; 449(7161): 390

24. Ledford H. HIV vaccine may raise risk. Nature. 2007; 450(7168): 325

25. Sirsi SR, Borden MA. Advances in ultrasound mediated gene therapy using microbubble contrast agents. Theranostics. 2012; 2(12): 1208-1222.

26. Naldini L, Blömer U, Gallay P, Ory D, Mulligan R, Gage FH, Verma IM, Trono $\mathrm{D}$. In vivo gene delivery and stable transduction of nondividing cells by a lentiviral vector. Science. 1996; 272(5259): 263-267.

27. Panje CM, Wang DS, Pysz MA, Paulmurugan R, Ren Y, Tranquart F, Tian L, Willmann JK. Ultrasound-mediated gene delivery with cationic versus neutral microbubbles: Effect of DNA and microbubble dose on in vivo transfection efficiency. Theranostics. 2012; 2(11): 1078-1091.

28. Gao X, Huang L. Cationic liposome-mediated gene transfer. Gene Ther. 1995; 2(10): 710-722.

29. Orio J, Coustets M, Mauroy C, Teissie J. Electric field orientation for gene delivery using high-voltage and low-voltage pulses. J Membr Biol. 2012; 245(10): 661-666

30. Robinson HL, Pertmer TM. Nucleic acid immunizations. Curr Protoc Immunol. 2001; Chapter 2: Unit 2.14.

31. Vu L, Ramos J, Potta T, Rege K. Generation of a focused poly (amino ether) library: polymer-mediated transgene delivery and gold-nanorod based theranostic systems. Theranostics. 2012; 2(12): 1160-1173.

32. Khosravi-Darani K, Mozafari MR, Rashidi L, Mohammadi M. Calcium based non-viral gene delivery: an overview of methodology and applications. Acta Med Iranica. 2010; 48(3): 133-141.
33. Luten J, van Nostrum CF, De Smedt SC, Hennink WE. Biodegradable polymers as non-viral carriers for plasmid DNA delivery. J Control Release. 2008; 126(2): 97-110.

34. Yamano S, Dai J, Moursi AM. Comparison of transfection efficiency of nonviral gene transfer reagents. Mol Biotechnol. 2010; 46(3): 287-300.

35. Keifer OP Jr, O'Connor DM, Boulis NM. Gene and protein therapies utilizing VEGF for ALS. Pharmacol Ther. 2013; doi: 10.1016/j.pharmthera.2013.10.009.

36. Edmundson $\mathrm{M}$, Thanh NT, Song B. Nanoparticles based stem cell tracking in regenerative medicine. Theranostics. 2013; 3(8): 573-582.

37. Li D, Liu S, Shan H, Conti P, Li Z. Urokinase plasminogen activator receptor (uPAR) targeted nuclear imaging and radionuclide therapy. Theranostics. 2013; 3(7): 507-515

38. Graham FL, Van der Eb AJ. A new technique for the assay of infectivity of human adenovirus 5 DNA. Virology. 1973; 52(2): 456-467.

39. Orrantia E, Chang PL. Intracellular distribution of DNA internalized through calcium phosphate precipitation. Exp Cell Res. 1990; 190(2): 170-174.

40. Cao X, Deng W, Wei Y, Su W, Yang Y, Wei Y, Yu J, Xu X. Encapsulation of plasmid DNA in calcium phosphate nanoparticles: stem cell uptake and gene transfer efficiency. Int J Nanomedicine. 2011; 6: 3335-3349.

41. Hu J, Kovtun A, Tomaszewski A, Singer BB, Seitz B, Epple M, Steuhl $\mathrm{KP}$, Ergün S, Fuchsluger TA. A new tool for the transfection of corneal endothelial cells: Calcium phosphate nanoparticles. Acta Biomater. 2012; 8(3): 1156-1163.

42. Kingston RE, Chen CA, Okayama H. Calcium phosphate transfection. Curr Protoc Immunol. 2001; Chapter 10:Unit 10.13.

43. Olton D, Li J, Wilson ME, Rogers T, Close J, Huang L, Kumta PN, Sfeir C. Nanostructured calcium phosphates (NanoCaPs) for non-viral gene delivery: Influence of the synthesis parameters on transfection efficiency. Biomaterials. 2007; 28(6): 1267-1279.

44. Sokolova V, Radtke I, Heumann R, Epple M. Effective transfection of cells with multi-shell calcium phosphate-DNA nanoparticles. Biomaterials. 2006; 27(16): 3147-3153.

45. Pedraza CE, Bassett DC, McKee MD, Nelea V, Gbureck U, Barralet JE. The importance of particle size and DNA condensation salt for calcium phosphate nanoparticle transfection. Biomaterials. 2008; 29(23): 3384-3392.

46. Elangovan S, Jain S, Tsai PC, Margolis HC, Amiji M. Nano-sized calcium phosphate particles for periodontal gene therapy. J Periodontol. 2013; 84(1): 117-125.

47. Nouri A, Castro R, Santos JL, Fernandes C, Rodrigues J, Tomás H. Calcium phosphate-mediated gene delivery using simulated body fluid (SBF). Int J Pharm. 2012; 434(1-2): 199-208.

48. Bhakta G, Shrivastava A, and Maitra A. Magnesium phosphate nanoparticles can be efficiently used in vitro and in vivo as non-viral vectors for targeted gene delivery. J Biomed Nanotechnol. 2009; 5(1): 106-114.

49. Pezzoli D, Kajaste-Rudnitski A, Chiesa R, Candiani G. Lipid-based nanoparticles as nonviral gene delivery vectors. Methods Mol Biol. 2013; 1025: 269-279.

50. Zhi D, Zhang S, Wang B, Zhao Y, Yang B, Yu S. Transfection efficiency of cationic lipids with different hydrophobic domains in gene delivery. Bioconjug Chem. 2010; 21(4): 563-577.

51. Felgner PL, Barenholz Y, Behr JP, Cheng SH, Cullis P, Huang L, Jessee JA, Seymour L, Szoka F, Thierry AR, Wagner E, Wu G. Nomenclature for synthetic gene delivery systems. Hum Gene Ther. 1997; 8(5): 511-512.

52. Gao K, Huang L. Nonviral methods for siRNA delivery. Pharm. 2009; 6(3): 651-658.

53. Zelphati O, Nguyen C, Ferrari M, Felgner J, Tsai Y, Felgner PL. Stable and monodisperse lipoplex formulations for gene delivery. Gene Ther. 1998; 5(9): $1272-1282$

54. Liu Y, Liggitt D, Zhong W, Tu G, Gaensler K, Debs R. Cationic liposome-mediated intravenous gene delivery. J Biol Chem. 1995; 42(270): 24864-24870

55. Stewart MJ, Plautz GE, Del BL, Yang ZY, Xu L, Gao X, Huang L, Nabel EG, Nabel GJ. Gene transfer in vivo with DNA-liposome complexes: safety and acute toxicity in mice. Hum Gene Ther. 1992; 3(3): 267-275.

56. Zhu N, Liggitt D, Liu Y, Debs R. Systemic gene expression after intravenous DNA delivery into adult mice. Science. 1993; 5118(261): 209-211.

57. Thierry AR, Lunardi-Iskandar Y, Bryant JL, Rabinovich P, Gallo RC, Mahan LC. Systemic gene therapy: biodistribution and long-term expression of a transgene in mice. Proc Natl Acad Sci U S A. 1995; 21(92): 9742-9746.

58. Mintzer MA, Simanek EE. Nonviral vectors for gene delivery. Chem Rev. 2009; 2(109): 259-302.

59. Bhattacharya S, Bajaj A. Advances in gene delivery through molecular design of cationic lipids. Chem Commun (Camb). 2009; 31: 4632-4656.

60. Martin B, Sainlos M, Aissaoui A, Oudrhiri N, Hauchecorne M, Vigneron JP, Lehn JM, Lehn P. The design of cationic lipids for gene delivery. Curr Pharm Des. 2005; 3(11): 375-394.

61. Escriou V, Ciolina C, Lacroix F, Byk G, Scherman D, Wils P. Cationic lipid-mediated gene transfer: effect of serum on cellular uptake and intracellular fate of lipopolyamine/DNA complexes. Biochim Biophys Acta. 1998; 2(1368): 276-288.

62. Zelphati O, Uyechi LS, Barron LG, Szoka FJ. Effect of serum components on the physico-chemical properties of cationic lipid/oligonucleotide complexes and on their interactions with cells. Biochim Biophys Acta. 1998; 2(1390): 119-133.

63. Klein E, Ciobanu M, Klein J, Machi V, Leborgne C, Vandamme T, Frisch B, Pons F, Kichler A, Zuber G, Lebeau L. "HFP" fluorinated cationic lipids for 
enhanced lipoplex stability and gene delivery. Bioconjug Chem. 2010; 2(21): 360-371.

64. Mevel M, Kamaly N, Carmona S, Oliver MH, Jorgensen MR, Crowther C, Salazar FH, Marion PL, Fujino M, Natori Y, Thanou M, Arbuthnot P, Yaouanc JJ, Jaffres PA, Miller AD. Dodag; A versatile new cationic lipid that mediates efficient delivery of pDNA and siRNA. J Control Release. 2010; 2(143): 222-232.

65. Morille M, Montier T, Legras P, Carmoy N, Brodin P, Pitard B, Benoit JP, Passirani C. Long-circulating DNA lipid nanocapsules as new vector for passive tumor targeting. Biomaterials. 2010; 2(31): 321-329.

66. Zhi D, Zhang S, Wang B, Zhao Y, Yang B, Yu S. Transfection efficiency of cationic lipids with different hydrophobic domains in gene delivery. Bioconjug Chem. 2010; 4(21): 563-577.

67. Lv H, Zhang S, Wang B, Cui S, Yan J. Toxicity of cationic lipids and cationic polymers in gene delivery. J Control Release. 2006; 1(114): 100-109.

68. Dobbs W, Heinrich B, Bourgogne C, Donnio B, Terazzi E, Bonnet ME, Stock F, Erbacher P, Bolcato-Bellemin AL, Douce L. Mesomorphic imidazolium salts: new vectors for efficient siRNA transfection. J Am Chem Soc. 2009; 37(131): 13338-13346.

69. Nie Y, Ji L, Ding H, Xie L, Li L, He B, Wu Y, Gu Z. Cholesterol derivatives based charged liposomes for doxorubicin delivery: preparation, in vitro and in vivo characterization. Theranostics. 2012; 2(11): 1092-1103.

70. Zhu L, Lu Y, Miller DD, Mahato RI. Structural and formulation factors influencing pyridinium lipid-based gene transfer. Bioconjug Chem. 2008; 12(19): 2499-2512.

71. Ahmad A, Evans HM, Ewert K, George CX, Samuel CE, Safinya CR. New multivalent cationic lipids reveal bell curve for transfection efficiency versus membrane charge density: lipid-DNA complexes for gene delivery. J Gene Med. 2005; 6(7): 739-748.

72. Nie Y, Ji L, Ding H, Xie L, Li L, He B, Wu Y, Gu Z. Cholesterol derivatives based charged liposomes for doxorubicin delivery: preparation, in vitro and in vivo characterization. Theranostics. 2012; 2(11): 1092-1103.

73. Liberska A, Unciti-Broceta A, Bradley M. Very long-chain fatty tails for enhanced transfection. Org Biomol Chem. 2009; 7(1): 61-68.

74. Bajaj A, Kondiah P, Bhattacharya S. Design, synthesis, and in vitro gene delivery efficacies of novel cholesterol-based gemini cationic lipids and their serum compatibility: a structure-activity investigation. J Med Chem. 2007; 50(10): 2432-2442.

75. Choi JS, Lee EJ, Jang HS, Park JS. New cationic liposomes for gene transfer into mammalian cells with high efficiency and low toxicity. Bioconjugate Chem. 2001; 1(12): 108-113.

76. Liu DL, Hu JJ, Qiao WH, Li ZS, Zhang SB, Cheng LB. Synthesis of carbamate-linked lipids for gene delivery. Bioorg Med Chem Lett. 2005; 12(15): 3147-3150.

77. Spelios M, Kearns M, Savva M. From gene delivery to gene silencing: plasmid DNA-transfecting cationic lipid 1,3-dimyristoylamidopropane-2-[bis(2-dimethylaminoethane)] carbamate efficiently promotes small interfering RNA-induced RNA interference. Biochemistry. 2010; 27(49): 5753-5759.

78. Yang HW, Yi JW, Bang EK, Jeon EM, Kim BH. Cationic nucleolipids as efficient siRNA carriers. Org Biomol Chem. 2011; 1(9): 291-296.

79. Li WJ, Szoka FC. Lipid-based nanoparticles for nucleic acid delivery. Pharm Res. 2007; 3(24): 438-449.

80. Xu XZ, Tu L, Wang LY, Fang XS, Wang DW. CYP2J3 gene delivery reduces insulin resistance via upregulation of eNOS in fructose-treated rats. Cardiovasc Diabetol. 2011; 10: 114

81. Nabel GJ, Nabel EG, Yang ZY, Fox BA, Plautz GE, Gao X, Huang L, Shu $S$, Gordon D, Chang AE. Direct gene transfer with DNA-liposome complexes in melanoma: Expression, biologicactivity, and lack of toxicity in humans. Proc Natl Acad Sci USA. 1993; 90(23): 11307-11311.

82. Leung SJ, Romanowski M. Light-activated content release from liposomes. Theranostics. 2012; 2(10): 1020-1036.

83. Zhang B, Ma XP, Murdoch W, Radosz M, Shen YQ. Bioreducible poly(amido amine)s with different branching degrees as gene delivery vectors. Biotechnol Bioeng. 2013; 3(110): 990-998.

84. Schaffert D, Troiber C, Wagner E. New sequence-defined polyaminoamides with tailored endosomolytic properties for plasmid DNA delivery. Bioconjugate Chem. 2012; 6(23): 1157-1165

85. Li WB, Yuan W, Xu FJ, Zhao C, Ma J, Zhan QM. Functional study of dextran-graft-poly ((2-dimethyl amino) ethyl methacrylate) gene delivery vector for tumor therapy. J Biomater Appl. 2013; 28(1): 125-35.

86. Wang YQ, Su J, Wu F, Lu P, Yuan LF, Yuan WE, Sheng J, Jin T. Biscarbamate cross-linked polyethylenimine derivative with low molecular weight, low cytotoxicity, and high efficiency for gene delivery. Int J Nanomedicine. 2012; 7: 693-704.

87. Zhou J, Liu J, Cheng CJ, Patel TR, Weller CE, Piepmeier JM, Jiang Z, Saltzman WM. Biodegradable poly(amine-co-ester) terpolymers for targeted gene delivery. Nat Mater. 2012; 1(11): 82-90.

88. Choi JS, Nam K, Park JY, Kim JB, Lee JK, Park JS. Enhanced transfection efficiency of PAMAM dendrimer by surface modification with l-arginine. J Control Release. 2004; 3(99): 445-456.

89. Pfeifer BA, Burdick JA, Little SR, Langer R. Poly(ester-anhydride): poly(beta-amino ester) micro- and nanospheres: DNA encapsulation and cellular transfection. Int J Pharm. 2005; 304(1-2): 210-219.
90. Anderson DG, Akinc A, Hossain N, Langer R. Structure/property studies of polymeric gene delivery using a library of poly(beta-amino esters). Mol Ther. 2005; 3(11): 426-434.

91. Hwang SJ, Bellocq NC, Davis ME. Effects of structure of beta-cyclodextrin-containing polymers on gene delivery. Bioconjugate Chem. 2001; 2(12): 280-290.

92. Kean $\mathrm{T}$, Roth $\mathrm{S}$, Thanou M. Trimethylated chitosans as non-viral gene delivery vectors: cytotoxicity and transfection efficiency. J Control Release. 2005; 3(103): 643-653.

93. Thanou M, Florea BI, Geldof M, Junginger HE, Borchard G. Quaternized chitosan oligomers as novel gene delivery vectors in epithelial cell lines. Biomaterials. 2002; 1(23): 153-159.

94. Bozkir A, Saka OM. Chitosan nanoparticles for plasmid DNA delivery: effect of chitosan molecular structure on formulation and release characteristics. Drug Deliv. 2004; 2(11): 107-112.

95. Borchard G. Chitosans for gene delivery. Adv Drug Deliver Rev. 2001; 2(52): $145-150$

96. Chandy T, Sharma CP. Chitosan - as a biomaterial. Biomater Artif Cells Artif Organs. 1990; 1(18): 1-24.

97. Rinaudo M. Main properties and current applications of some polysaccharides as biomaterials. Polym Int. 2008; 3(57): 397-430.

98. Mourya VK, Inamdar NN. Chitosan-modifications and applications: opportunities galore. React Funct Polym. 2008; 6(68): 1013-1051.

99. Howard KA, Rahbek UL, Liu X, Damgaard CK, Glud SZ, Andersen MO, Hovgaard MB, Schmitz A, Nyengaard JR, Besenbacher F, Kjems J. RNA interference in vitro and in vivo using a novel chitosan/siRNA nanoparticle system. Mol Ther. 2006; 4(14): 476-484.

100. Lavertu M, Methot S, Tran-Khanh N, Buschmann MD. High efficiency gene transfer using chitosan/DNA nanoparticles with specific combinations of molecular weight and degree of deacetylation. Biomaterials. 2006; 27(27): 4815-4824.

101. He XK, Yuan ZX, Wu XJ, Xu CQ, Li WY. Low molecular weight hydroxyethyl chitosan-prednisolone conjugate for renal targeting therapy: synthesis, characterization and in vivo studies. Theranostics. 2012; 2(11): 1054-1063.

102. Prabaharan M, Mano JF. Chitosan-based particles as controlled drug delivery systems. Drug Deliv. 2005; 1(12): 41-57.

103. Lai WF, Lin M. Nucleic acid delivery with chitosan and its derivatives. J Control Release. 2009; 3(134): 158-168.

104. Mao SR, Sun W, Kissel T. Chitosan-based formulations for delivery of DNA and siRNA. Adv Drug Deliver Rev. 2010; 1(62): 12-27.

105. Sato $\mathrm{T}$, Ishii $\mathrm{T}$, Okahata $\mathrm{Y}$. In vitro gene delivery mediated by chitosan. Effect of $\mathrm{pH}$, serum, and molecular mass of chitosan on the transfection efficiency. Biomaterials. 2001; 15(22): 2075-2080.

106. Turan K, Nagata K. Chitosan-DNA nanoparticles: the effect of cell type and hydrolysis of chitosan on in vitro DNA transfection. Pharm Dev Technol. 2006; 4(11): 503-512.

107. Sajomsang W, Gonil P, Ruktanonchai UR, Petchsangsai M, Opanasopit P, Puttipipatkhachorn S. Effects of molecular weight and pyridinium moiety on water-soluble chitosan derivatives for mediated gene delivery. Carbohyd Polym. 2013; 2(91): 508-517.

108. Sarkar K, Kundu PP. PAMAM conjugated chitosan through naphthalimide moiety for enhanced gene transfection efficiency. Carbohydr Polym. 2013; 98(1): 495-504

109. Wang BQ, He CB, Tang C, Yin CH. Effects of hydrophobic and hydrophilic modifications on gene delivery of amphiphilic chitosan based nanocarriers. Biomaterials. 2011; 20(32): 4630-4638.

110. Danielsen S, Strand S, Davies CD, Stokke BT. Glycosaminoglycan destabilization of DNA-chitosan polyplexes for gene delivery depends on chitosan chain length and GAG properties. Biochim Biophys Acta. 2005; 1721(1-3): 44-54.

111. Mansouri S, Lavigne P, Corsi K, Benderdour M, Beaumont E, Fernandes JC. Chitosan-DNA nanoparticles as non-viral vectors in gene therapy: strategies to improve transfection efficacy. Eur J Pharm Biopharm. 2004; 1(57): 1-8.

112. Zhou XF, Zhang XH, Yu XH, Zha X, Fu Q, Liu B, Wan X, Chen Y, Chen Y, Shan YM, Jin YH, Wu YG, Liu JQ, Kong W, Shen JC. The effect of conjugation to gold nanoparticles on the ability of low molecular weight chitosan to transfer DNA vaccine. Biomaterials. 2008; 1(29): 111-117.

113. Lavertu M, Methot S, Tran-Khanh N, Buschmann MD. High efficiency gene transfer using chitosan/DNA nanoparticles with specific combinations of molecular weight and degree of deacetylation. Biomaterials. 2006; 27(27): 4815-4824.

114. Chae SY, Son S, Lee M, Jang MK, Nah JW. Deoxycholic acid-conjugated chitosan oligosaccharide nanoparticles for efficient gene carrier. J Control Release. 2005; 109(1-3): 330-344.

115. Liu WG, Zhang X, Sun SJ, Sun GJ, De Yao K, Liang DC, Guo G, Zhang JY. $\mathrm{N}$-alkylated chitosan as a potential nonviral vector for gene transfection. Bioconjugate Chem. 2003; 4(14): 782-789.

116. Lee D, Zhang W, Shirley SA, Kong X, Hellermann GR, Lockey RF, Mohapatra SS. Thiolated chitosan/DNA nanocomplexes exhibit enhanced and sustained gene delivery. Pharm Res. 2007; 1(24): 157-167.

117. Liu ZH, Zhang ZY, Zhou CR, Jiao YP. Hydrophobic modifications of cationic polymers for gene delivery. Prog Polym Sci. 2010; 9(35): 1144-1162.

118. Mao SR, Sun W, Kissel T. Chitosan-based formulations for delivery of DNA and siRNA. Adv Drug Deliver Rev. 2010; 1(62): 12-27.

119. Germershaus O, Mao SR, Sitterberg J, Bakowsky U, Kissel T. Gene delivery using chitosan, trimethyl chitosan or polyethylenglycol-graft-trimethyl chi- 
tosan block copolymers: establishment of structure-activity relationships in vitro. J Control Release. 2008; 2(125): 145-154.

120. Chan P, Kurisawa M, Chung JE, Yang YY. Synthesis and characterization of chitosan-g-poly(ethylene glycol)-folate as a non-viral carrier for tumor-targeted gene delivery. Biomaterials. 2007; 3(28): 540-549.

121. Zhao X, Yin LC, Ding JY, Tang C, Gu SH, Yin CH, Mao YM. Thiolated trimethyl chitosan nanocomplexes as gene carriers with high in vitro and in vivo transfection efficiency. J Control Release. 2010; 1(144): 46-54.

122. Zhou HF, Yu WT, Guo X, Liu XD, Li N, Zhang Y, Ma XJ. Synthesis and characterization of amphiphilic glycidol-chitosan-deoxycholic acid nanoparticles as a drug carrier for doxorubicin. Biomacromolecules. 2010; 12(11): 3480-3486.

123. Lavertu M, Methot S, Tran-Khanh N, Buschmann MD. High efficiency gene transfer using chitosan/DNA nanoparticles with specific combinations of molecular weight and degree of deacetylation. Biomaterials. 2006; 27(27): 4815-4824.

124. Nimesh S, Thibault MM, Lavertu M, Buschmann MD. Enhanced gene delivery mediated by low molecular weight chitosan/DNA complexes: effect of $\mathrm{pH}$ and serum. Mol Biotechnol. 2010; 2(46): 182-196.

125. Thibault M, Nimesh S, Lavertu M, Buschmann MD. Intracellular trafficking and decondensation kinetics of chitosan-pDNA polyplexes. Mol Ther. 2010; 10(18): 1787-1795.

126. Masotti A, Bordi F, Ortaggi G, Marino F, Palocci C. A novel method to obtain chitosan/DNA nanospheres and a study of their release properties. Nanotechnology. 2008; 19(5): 055302.

127. Dai H, Jiang X, Tan GC, Chen Y, Torbenson M, Leong KW, Mao HQ. Chitosan-DNA nanoparticles delivered by intrabiliary infusion enhance liver-targeted gene delivery. Int. J. Nanomed. 2006; 4(1): 507-522.

128. Lee JI, Kim HS, Yoo HS. DNA nanogels composed of chitosan and pluronic with thermo-sensitive and photo-crosslinking properties. Int J Pharm. 2009; 373(1-2): 93-99.

129. Park SC, Nam JP, Kim YM, Kim JH, Nah JW, Jang MK. Branched polyethylenimine-grafted-carboxymethyl chitosan copolymer enhances the delivery of pDNA or siRNA in vitro and in vivo. Int J Nanomedicine. 2013; 8: 3663-77.

130. Liu CC, Zhu Q, Wu WH, Xu XL, Wang XY, Gao S, Liu KH. Degradable copolymer based on amphiphilic N-octyl-N-quatenary chitosan and low-molecular weight polyethylenimine for gene delivery. Int J Nanomed. 2012; 7: 5339-5350.

131. De Laporte L, Rea JC, Shea LD. Design of modular non-viral gene therapy vectors. Biomaterials. 2006; 7(27): 947-954.

132. Brown MD, Schatzlein AG, Uchegbu IF. Gene delivery with synthetic (non-viral) carriers. Int J Pharm. 2001; 229(1-2): 1-21.

133. Dai ZJ, Gjetting T, Mattebjerg MA, Wu C, Andresen TL. Elucidating the interplay between DNA-condensing and free polycations in gene transfection through a mechanistic study of linear and branched PEI. Biomaterials. 2011; 33(32): 8626-8634.

134. Nimesh S, Goyal A, Pawar V, Jayaraman S, Kumar P, Chandra R, Singh Y, Gupta KC. Polyethylenimine nanoparticles as efficient transfecting agents for mammalian cells. J Control Release. 2006; 110(2): 457-468.

135. Nimesh S, Aggarwal A, Kumar P, Singh Y, Gupta KC, Chandra R. Influence of acyl chain length on transfection mediated by acylated PEI nanoparticles. Int J Pharm. 2007; 337(1-2): 265-274.

136. Vu L, Ramos J, Potta T, Rege K. Generation of a focused poly (amino ether) library: polymer-mediated transgene delivery and gold-nanorod based theranostic systems. Theranostics. 2012; 2(12): 1160-1173.

137. Boeckle S, von Gersdorff K, van der Piepen S, Culmsee C, Wagner E, Ogris M. Purification of polyethylenimine polyplexes highlights the role of free polycations in gene transfer. J Gene Med. 2004; 10(6): 1102-1111.

138. Boussif O, Lezoualch F, Zanta MA, Mergny MD, Scherman D, Demeneix B, Behr JP. A versatile vector for gene and oligonucleotide transfer into cells in culture and in-vivo polyethylenimine. Proc Natl Acad Sci U S A. 1995; 16(92): 7297-7301.

139. Zou SM, Erbacher P, Remy JS, Behr JP. Systemic linear polyethylenimine (1-PEI)-mediated gene delivery in the mouse. J Gene Med. 2000; 2(2): 128-134.

140. Fischer D, Bieber T, Li YX, Elsasser HP, Kissel T. A novel non-viral vector for DNA delivery based on low molecular weight, branched polyethylenimine: effect of molecular weight on transfection efficiency and cytotoxicity. Pharm Res. 1999; 8(16): 1273-1279.

141. Dunlap DD, Maggi A, Soria MR, Monaco L. Nanoscopic structure of DNA condensed for gene delivery. Nucleic Acids Res. 1997; 15(25): 3095-3101.

142. Kawakami S, Ito Y, Charoensit P, Yamashita F, Hashida M. Evaluation of proinflammatory cytokine production induced by linear and branched polyethylenimine/plasmid DNA complexes in mice. J Pharmacol Exp Ther. 2006; 3(317): 1382-1390.

143. Moghimi SM, Symonds P, Murray JC, Hunter AC, Debska G, Szewczyk A. A two-stage poly(ethylenimine)-mediated cytotoxicity: implications for gene transfer/therapy. Mol Ther. 2005; 6(11): 990-995.

144. Godbey WT, Wu KK, Mikos AG. Poly(ethylenimine) and its role in gene delivery. J Control Release. 1999; 2-3(60): 149-160.

145. Thomas M, Klibanov AM. Non-viral gene therapy: polycation-mediated DNA delivery. Appl Microbiol Biot. 2003; 1(62): 27-34.

146. Kunath K, von Harpe A, Fischer D, Peterson H, Bickel U, Voigt K, Kissel T. Low-molecular-weight polyethylenimine as a non-viral vector for DNA delivery: comparison of physicochemical properties, transfection efficiency and in vivo distribution with high-molecular-weight polyethylenimine. J Control Release. 2003; 1(89): 113-125.
147. De Smedt SC, Demeester J, Hennink WE. Cationic polymer based gene delivery systems. Pharm Res. 2000; 2(17): 113-126.

148. Yang CA, Li HZ, Goh SH, Li J. Cationic star polymers consisting of alpha-cyclodextrin core and oligoethylenimine arms as nonviral gene delivery vectors. Biomaterials. 2007; 21(28): 3245-3254.

149. Deng R, Yue Y, Jin F, Chen YC, Kung HF, Lin M, Wu C. Revisit the complexation of PEI and DNA - how to make low cytotoxic and highly efficient PEI gene transfection non-viral vectors with a controllable chain length and structure? J Control Release. 2009; 1(140): 40-46.

150. Merkel OM, Urbanics R, Bedocs P, Rozsnyay Z, Rosivall L, Toth M, Kissel T, Szebeni J. In vitro and in vivo complement activation and related anaphylactic effects associated with polyethylenimine and polyethylenimine-graft-poly(ethylene glycol) block copolymers. Biomaterials. 2011; 21(32): 4936-4942.

151. Fischer D, Bieber T, Li YX, Elsasser HP, Kissel T. A novel non-viral vector for DNA delivery based on low molecular weight, branched polyethylenimine: effect of molecular weight on transfection efficiency and cytotoxicity. Pharm Res. 1999; 8(16): 1273-1279.

152. Gosselin MA, Guo WJ, Lee RJ. Efficient gene transfer using reversibly cross-linked low molecular weight polyethylenimine. Bioconjugate Chem. 2001; 6(12): 989-994.

153. Breunig M, Lungwitz U, Liebl R, Goepferich A. Breaking up the correlation between efficacy and toxicity for nonviral gene delivery. Proc Natl Acad Sci USA. 2007; 36(104): 14454-14459.

154. Breunig M, Lungwitz U, Liebl R, Goepferich A. Fluorescence resonance energy transfer: evaluation of the intracellular stability of polyplexes. Eur J Pharm Biopharm. 2006; 2(63): 156-165.

155. Choi S, Lee KD. Enhanced gene delivery using disulfide-crosslinked low molecular weight polyethylenimine with listeriolysin o-polyethylenimine disulfide conjugate. J Control Release. 2008; 1(131): 70-76.

156. Deng R, Diao S, Yue YN, Ngai T, Wu C, Jin F. Dynamic and structural scalings of the complexation between pDNA and bPEI in semidilute and low-salt solutions. Biopolymers. 2010; 6(93): 571-577.

157. Peng Q, Zhong ZL, Zhuo RX. Disulfide cross-linked polyethylenimines (PEI) prepared via thiolation of low molecular weight PEI as highly efficient gene vectors. Bioconjugate Chem. 2008; 2(19): 499-506.

158. Knorr V, Ogris M, Wagner E. An acid sensitive ketal-based polyethylene glycol-oligoethylenimine copolymer mediates improved transfection efficiency at reduced toxicity. Pharm Res. 2008; 12(25): 2937-2945.

159. Kloeckner J, Bruzzano S, Ogris M, Wagner E. Gene carriers based on hexanediol diacrylate linked oligoethylenimine: effect of chemical structure of polymer on biological properties. Bioconjugate Chem. 2006; 5(17): 1339-1345.

160. Pathak A, Swami A, Patnaik S, Jain S, Chuttani K, Mishra AK, Vyas SP, Kumar P, Gupta KC. Efficient tumor targeting by polysaccharide decked polyethylenimine based nanocomposites. J Biomed Nanotechnol. 2009; 3(5): 264-277.

161. Forrest ML, Koerber JT, Pack DW. A degradable polyethylenimine derivative with low toxicity for highly efficient gene delivery. Bioconjugate Chem. 2003; 5(14): 934-940.

162. Lin C, Engbersen J. The role of the disulfide group in disulfide-based polymeric gene carriers. Expert. Opin. Drug Deliv. 2009; 4(6): 421-439.

163. Endres TK, Beck-Broichsitter M, Samsonova O, Renette T, Kissel TH. Self-assembled biodegradable amphiphilic PEG-PCL-IPEI triblock copolymers at the borderline between micelles and nanoparticles designed for drug and gene delivery. Biomaterials. 2011; 30(32): 7721-7731.

164. Han SO, Mahato RI, Kim SW. Water-soluble lipopolymer for gene delivery. Bioconjugate Chem. 2001; 3(12): 337-345.

165. Lee M, Rentz J, Han SO, Bull DA, Kim SW. Water-soluble lipopolymer as an efficient carrier for gene delivery to myocardium. Gene Ther. 2003; 7(10): 585-593.

166. Aliabadi HM, Landry B, Bahadur RK, Neamnark A, Suwantong O, Uludag H. Impact of lipid substitution on assembly and delivery of siRNA by cationic polymers. Macromol Biosci. 2011; 5(11): 662-672.

167. Bahadur K, Landry B, Aliabadi HM, Lavasanifar A, Uludag H. Lipid substitution on low molecular weight $(0.6-2.0 \mathrm{kDa})$ polyethylenimine leads to a higher zeta potential of plasmid DNA and enhances transgene expression. Acta Biomater. 2011; 5(7): 2209-2217.

168. Liu ZH, Zhang ZY, Zhou CR, Jiao YP. Hydrophobic modifications of cationic polymers for gene delivery. Prog Polym Sci. 2010; 9(35): 1144-1162.

169. Liu ZZ, Zheng M, Meng FH, Zhong ZY. Non-viral gene transfection in vitro using endosomal $\mathrm{pH}$-sensitive reversibly hydrophobilized polyethylenimine. Biomaterials. 2011; 34(32): 9109-9119.

170. Mahato RI. Water insoluble and soluble lipids for gene delivery. Adv Drug Deliver Rev. 2005; 5(57): 699-712.

171. Forrest ML, Koerber JT, Pack DW. A degradable polyethylenimine derivative with low toxicity for highly efficient gene delivery. Bioconjugate Chem. 2003; 5(14): 934-940.

172. Thomas M, Ge Q, Lu JJ, Chen JZ, Klibanov AM. Cross-linked small polyethylenimines: while still nontoxic, deliver DNA efficiently to mammalian cells in vitro and in vivo. Pharm Res. 2005; 3(22): 373-380.

173. Liu TT, Yu XJ, Kan B, Guo QF, Wang XH, Shi SA, Guo G, Luo F, Zhao X, Wei YQ, Qian ZY. Enhanced gene delivery using biodegradable poly(ester amine)s (PEAs) based on low-molecular-weight polyethylenimine and poly(epsilon-caprolactone)-pluronic-poly(epsilon -caprolactone). J Biomed Nanotechnol. 2010; 4(6): 351-359. 
174. Arote R, Kim TH, Kim YK, Hwang SK, Jiang HL, Song HH, Nah JW, Cho MH, Cho CS. A biodegradable poly(ester amine) based on polycaprolactone and polyethylenimine as a gene carrier. Biomaterials. 2007; 4(28): 735-744.

175. Bauhuber S, Hozsa C, Breunig M, Gopferich A. Delivery of nucleic acids via disulfide-based carrier systems. Adv Mater. 2009; 21(32-33): 3286-3306.

176. Goyal R, Tripathi SK, Tyagi S, Ram KR, Ansari KM, Kumar P, Shukla Y, Chowdhuri DK, Gupta KC. Gellan gum-PEI nanocomposites as efficient gene delivery agents. J Biomed Nanotechnol. 2011; 7(1): 38-39.

177. Navarro G, de Ilarduya CT. Activated and non-activated PAMAM dendrimers for gene delivery in vitro and in vivo. Nanomedicine . 2009; 3(5): 287-297.

178. Wen YT, Guo ZH, Du Z, Fang R, Wu HM, Zeng X, Wang C, Feng M, Pan SR. Serum tolerance and endosomal escape capacity of histidine-modified pDNA-loaded complexes based on polyamidoamine dendrimer derivatives. Biomaterials. 2012; 32(33): 8111-8121.

179. Yin Z, Liu N, Ma MS, Wang L, Hao YL, Zhang XN. A novel EGFR-targeted gene delivery system based on complexes self-assembled by EGF, DNA, and activated PAMAM dendrimers. Int J Nanomedicine. 2012; 7: 4625-4635.

180. Malik N, Wiwattanapatapee R, Klopsch R, Lorenz K, Frey H, Weener JW, Meijer EW, Paulus W, Duncan R. Dendrimers: relationship between structure and biocompatibility in vitro, and preliminary studies on the biodistribution of 125I-labelled polyamidoamine dendrimers in vivo. J Control Release. 2000; 65(1-2): 133-148.

181. Han MH, Chen J, Wang J, Chen SL, Wang XT. In vivo delivery of Atoh1 gene to rat cochlea using a dendrimer-based nanocarrier. J Biomed Nanotechnol. 2013; 9(10): 1736-1745.

182. Cao D, Qin L, Huang H, Feng M, Pan S, Chen J. Transfection activity and the mechanism of pDNA-complexes based on the hybrid of low-generationPAMAM and branched PEI-1.8k. Mol Biosyst. 2013; 9(12): 3175-3186.

183. Dobrovolskaia MA, Patri AK, Simak J, Hall JB, Semberova J, Lacerda S, McNeil SE. Nanoparticle size and surface charge determine effects of PAMAM dendrimers on human platelets in vitro. Mol Pharm. 2012; 3(9): 382-393.

184. Cloninger MJ. Biological applications of dendrimers. Curr Opin Chem Biol. 2002; 6(6): 742-748

185. Lee CC, MacKay JA, Frechet J, Szoka FC. Designing dendrimers for biological applications. Nat Biotechnol. 2005; 12(23): 1517-1526.

186. Daneshvar N, Abdullah R, Shamsabadi FT, How CW, Aizat M, Mehrbod P. PAMAM dendrimer roles in gene delivery methods and stem cell research. Cell Biol Int. 2013; 5(37): 415-419.

187. KukowskaLatallo JF, Bielinska AU, Johnson J, Spindler R, Tomalia DA, Baker JR. Efficient transfer of genetic material into mammalian cells using starburst polyamidoamine dendrimers. Proc Natl Acad Sci USA. 1996; 10(93): 4897-4902.

188. Bielinska A, Kukowskalatallo J, Piehler LT, Yin R, Spindler R, Tomalia DA, Baker JR. Starburst(R) PAMAM dendrimers - a novel synthetic vector for the transfection of DNA into mammalian cells. Abstr Pap Am Chem Soc. 1995; 210(Part 2): 145

189. Killops KL, Campos LM, Hawker CJ. Robust, efficient, and orthogonal synthesis of dendrimers via thiolene "click" chemistry. J Am Chem Soc. 2008; 15(130): 5062.

190. Shah N, Steptoe RJ, Parekh HS. Low-generation asymmetric dendrimers exhibit minimal toxicity and effectively complex DNA. J Pept Sci. 2011; 6(17): 470-478.

191. Pan SR, Cao DW, Huang H, Yi W, Qin LH, Feng M. A serum-resistant low-generation polyamidoamine with PEI 423 outer layer for gene delivery vector. Macromol Biosci. 2013; 4(13): 422-436.

192. Liu HM, Wang H, Yang WJ, Cheng YY. Disulfide cross-linked low generation dendrimers with high gene transfection efficacy, low cytotoxicity, and low cost. J Am Chem Soc. 2012; 42(134): 17680-17687.

193. Nakhlband A, Barar J, Bidmeshkipour A, Heidari HR, Omidi Y. Bioimpacts of anti epidermal growth factor receptor antisense complexed with polyamidoamine dendrimers in human lung epithelial adenocarcinoma cells. J Biomed Nanotechnol. 2010; 4(6): 360-369.

194. Kim JB, Choi JS, Nam K, Lee M, Park JS, Lee JK. Enhanced transfection of primary cortical cultures using arginine-grafted PAMAM dendrimer, PAMAM-arg. J Control Release. 2006; 1(114): 110-117.

195. Santos JL, Oliveira H, Pandita D, Rodrigues J, Pego AP, Granja PL, Tomas H. Functionalization of poly(amidoamine) dendrimers with hydrophobic chains for improved gene delivery in mesenchymal stem cells. J Control Release. 2010; 1(144): 55-64

196. Luo K, Li CX, Li L, She WC, Wang G, Gu ZW. Arginine functionalized peptide dendrimers as potential gene delivery vehicles. Biomaterials. 2012; 19(33): 4917-4927.

197. Nam HY, Nam K, Hahn HJ, Kim BH, Lim HJ, Kim HJ, Choi JS, Park JS. Biodegradable PAMAM ester for enhanced transfection efficiency with low cytotoxicity. Biomaterials. 2009; 4(30): 665-673.

198. Kono K, Akiyama H, Takahashi T, Takagishi T, Harada A. Transfection activity of polyamidoamine dendrimers having hydrophobic amino acid residues in the periphery. Bioconjugate Chem. 2005; 1(16): 208-214.

199. Sanclimens G, Shen H, Giralt E, Albericio F, Saltzman MW, Royo M. Synthesis and screening of a small library of proline-based biodendrimers for use as delivery agents. Biopolymers. 2005; 6(80): 800-814.

200. Kang CS, Yuan XB, Li F, Pu PY, Yu SZ, Shen CH, Zhang ZY, Zhang YT. Evaluation of folate-PAMAM for the delivery of antisense oligonucleotides to rat C6 glioma cells in vitro and in vivo. J Biomed Mater Res. 2010; 2(93A): 585-594.
201. Wada K, Arima H, Tsutsumi T, Chihara Y, Hattori K, Hirayama F, Uekama K. Improvement of gene delivery mediated by mannosylated dendrimer/alpha-cyclodextrin conjugates. J Control Release. 2005; 2(104): 397-413.

202. Arima $\mathrm{H}$, Yamashita $\mathrm{S}$, Mori $\mathrm{Y}$, Hayashi $\mathrm{Y}$, Motoyama $\mathrm{K}$, Hattori $\mathrm{K}$, Takeuchi $\mathrm{T}$, Jono $\mathrm{H}$, Ando $\mathrm{Y}$, Hirayama $\mathrm{F}$, Uekama $\mathrm{K}$. In vitro and in vivo gene delivery mediated by lactosylated dendrimer/alpha-cyclodextrin conjugates (g2) into hepatocytes. J Control Release. 2010; 1(146): 106-117.

203. Wada K, Arima H, Tsutsumi T, Hirayama F, Uekama K. Enhancing effects of galactosylated dendrimer/alpha-cyclodextrin conjugates on gene transfer efficiency. Biol Pharm Bull. 2005; 3(28): 500-505.

204. Zhang Q, Chen S, Zhuo RX, Zhang XZ, Cheng SX. Self-assembled terplexes for targeted gene delivery with improved transfection. Bioconjugate Chem. 2010; 11(21): 2086-2092.

205. Huang RQ, Qu YH, Ke WL, Zhu JH, Pei YY, Jiang C. Efficient gene delivery targeted to the brain using a transferrin-conjugated polyethyleneglycol-modified polyamidoamine dendrimer. Faseb J. 2007; 4(21): 1117-1125.

206. Han LA, Huang RQ, Li JF, Liu SH, Huang SX, Jiang C. Plasmid pORF-hTRAIL and doxorubicin co-delivery targeting to tumor using peptide-conjugated polyamidoamine dendrimer. Biomaterials. 2011; 4(32): 1242-1252.

207. Cui DX, Huang P, Zhang CL, Ozkan CS, Pan BF, Xu P. Dendrimer-modified gold nanorods as efficient controlled gene delivery system under near-infrared light irradiation. J Control Release. 2011; 152Suppl1: E137-E139.

208. Shan YB, Luo T, Peng C, Sheng RL, Cao AM, Cao XY, Shen MW, Guo R, Tomas $\mathrm{H}$, Shi $\mathrm{XY}$. Gene delivery using dendrimer-entrapped gold nanoparticles as nonviral vectors. Biomaterials. 2012; 10(33): 3025-3035.

209. Herrero MA, Toma FM, Al-Jamal KT, Kostarelos K, Bianco A, Da Ros T, Bano F, Casalis L, Scoles G, Prato M. Synthesis and characterization of a carbon nanotube-dendron series for efficient siRNA delivery. J Am Chem Soc. 2009; 28(131): 9843-9848

210. Breunig M, Lungwitz U, Liebl R, Goepferich A. Breaking up the correlation between efficacy and toxicity for nonviral gene delivery. Proc Natl Acad Sci U S A. 2007; 36(104): 14454-14459.

211. Kihara F, Arima H, Tsutsumi T, Hirayama F, Uekama K. Effects of structure of polyamidoamine dendrimer on gene transfer efficiency of the dendrimer conjugate with alpha-cyclodextrin. Bioconjugate Chem. 2002; 6(13): 1211-1219.

212. Lee JH, Lim YB, Choi JS, Lee Y, Kim TI, Kim HJ, Yoon JK, Kim K, Park JS. Polyplexes assembled with internally quaternized PAMAM-OH dendrimer and plasmid DNA have a neutral surface and gene delivery potency. Bioconjugate Chem. 2003; 6(14): 1214-1221.

213. Patil ML, Zhang M, Betigeri S, Taratula O, He H, Minko T. Surface-modified and internally cationic polyamidoamine dendrimers for efficient siRNA delivery. Bioconjugate Chem. 2008; 7(19): 1396-1403.

214. Sun XL, Zhang N. Cationic polymer optimization for efficient gene delivery. Mini. Rev. Med. Chem. 2010; 2(10): 108-125.

215. Zhou JH, Wu JY, Hafdi N, Behr JP, Erbacher P, Peng L. PAMAM dendrimers for efficient siRNA delivery and potent gene silencing. Chem Commun. 2006; (22): 2362-2364.

216. Aydin Z, Akbas F, Senel M, Koc SN. Evaluation of Jeffamine ${ }^{\circledR}$-cored PAMAM dendrimers as an efficient in vitro gene delivery system. J Biomed Mater Res A. $2012 ; 10(100)$ : 2623-2628

217. Tang MX, Redemann CT, Szoka FC. In vitro gene delivery by degraded polyamidoamine dendrimers. Bioconjugate Chem. 1996; 6(7): 703-714.

218. Bhakta G, Shrivastava A, Maitra A. Magnesium phosphate nanoparticles can be efficiently used in vitro and in vivo as non-viral vectors for targeted gene delivery. J. Biomed. Nanotechnol. 2009; 1(5): 106-114.

219. Langer R. Drug delivery and targeting. Nature. 1998; 392(6679 Suppl): 5-10.

220. Pedone E, Cavallaro G, Richardson S, Duncan R, Giammona G. Alpha, beta-poly(asparthylhydrazide)-glycidyltrimethylammonium chloride copolymers (PAHy-GTA): novel polymers with potential for DNA delivery. J Control Release. 2001; 77(1-2): 139-153.

221. Kang HC, Lee M, Bae YH. Polymeric gene carriers. Crit Rev Eukar Gene. 2005; 4(15): 317-342.

222. Chemin I, Moradpour D, Wieland S, Offensperger WB, Walter E, Behr JP, Blum HE. Liver-directed gene transfer: a linear polyethylenimine derivative mediates highly efficient DNA delivery to primary hepatocytes in vitro and in vivo. J Viral Hepatitis. 1998; 6(5): 369-375.

223. Blum JS, Saltzman WM. High loading efficiency and tunable release of plasmid DNA encapsulated in submicron particles fabricated from PLGA conjugated with poly-l-lysine. J Control Release. 2008; 1(129): 66-72.

224. Shah B, Kona S, Gilbertson TA, Nguyen KT. Effects of poly-(lactide-co-glycolide) nanoparticles on electrophysiological properties of enteroendocrine cells. J Nanosci Nanotechnol. 2011;11(4): 3533-3542.

225. Hedley ML. Formulations containing poly(lactide-co-glycolide) and plasmid DNA expression vectors. Expert Opin Biol Th. 2003; 6(3): 903-910.

226. Walter E, Dreher D, Kok M, Thiele L, Kiama SG, Gehr P, Merkle HP. Hydrophilic poly(dl-lactide-co-glycolide) microspheres for the delivery of DNA to human-derived macrophages and dendritic cells. J Control Release. 2001; 76(1-2): 149-168.

227. Wang DQ Robinson DR, Kwon GS, Samuel J. Encapsulation of plasmid DNA in biodegradable poly(d,l-lactic-co-glycolic acid) microspheres as a novel approach for immunogene delivery. J Control Release. 1999; 1(57): 9-18.

228. Denis-Mize KS, Dupuis M, Singh M, Woo C, Ugozzoli M, O'Hagan DT, Donnelly JJ, Ott G, McDonald DM. Mechanisms of increased immunogenicity for DNA-based vaccines adsorbed onto cationic microparticles. Cell Immunol. 2003; 1(225): 12-20. 
229. He XW, Jiang L, Wang F, Xiao ZY, Li J, Liu LS, Li D, Ren D, Jin XQ, Li K, He Y, Shi K, Guo YJ, Zhang YN, Sun SH. Augmented humoral and cellular immune responses to hepatitis B DNA vaccine adsorbed onto cationic microparticles. J Control Release. 2005; 2(107): 357-372.

230. He XW, Wang F, Jiang L, Li J, Liu SK, Xiao ZY, Jin XQ, Zhang YN, He Y, Li K, Guo YJ, Sun SH. Induction of mucosal and systemic immune response by single-dose oral immunization with biodegradable microparticles containing DNA encoding HBsAg. J Gen Virol. 2005; 3(86): 601-610.

231. Lima KM, Santos SA, Lima V, Coelho-Castelo A, Rodrigues JM, Silva CL. Single dose of a vaccine based on DNA encoding mycobacterial hsp65 protein plus TDM-loaded PLGA microspheres protects mice against a virulent strain of mycobacterium tuberculosis. Gene Ther. 2003; 8(10): 678-685.

232. Coelho E, Tavares C, Lima KD, Silva CL, Rodrigues JM, Fernandes AP. Mycobacterium hsp65 DNA entrapped into TMD-loaded PLGA microspheres induces protection in mice against leishmania (leishmania) major infection. Parasitol Res. 2006; 6(98): 568-575.

233. Galindo-Rodriguez SA, Allemann E, Fessi H, Doelker E. Polymeric nanoparticles for oral delivery of drugs and vaccines: a critical evaluation of in vivo studies. Crit Rev Ther Drug. 2005; 5(22): 419-463.

234. Kumar M, Mohapatra SS, Kong X, Jena PK, Bakowsky U, Lehr CM. Cationic poly(lactide-co-glycolide) nanoparticles as efficient in vivo gene transfection agents. J Nanosci Nanotechnol. 2004; 8(4): 990-994.

235. Walter E, Moelling K, Pavlovic J, Merkle HP. Microencapsulation of DNA using poly(dl-lactide-co-glycolide): stability issues and release characteristics. J Control Release. 1999; 3(61): 361-374

236. Zhu GZ, Mallery SR, Schwendeman SP. Stabilization of proteins encapsulated in injectable poly (lactide-co-glycolide). Nat Biotechnol. 2000; 1(18): 52-57.

237. Li YP, Ogris M, Pelisek J, Roedl W. Stability and release characteristics of poly(d,l-lactide-co-glycolide) encapsulated CaPi-DNA coprecipitation. Int J Pharm. 2004; 1(269): 61-70.

238. Aral C, Akbuga J. Preparation and in vitro transfection efficiency of chitosan microspheres containing plasmid DNA : poly(l-lysine) complexes. J Pharm Pharm Sci. 2003; 3(6): 321-326

239. Tinsley-Bown AM, Fretwell R, Dowsett AB, Davis SL, Farrar GH. Formulation of poly(d,l-lactic-co-glycolic acid) microparticles for rapid plasmid DNA delivery. J Control Release. 2000; 66(2-3): 229-241.

240. Orrantia E, Chang PL. Intracellular-distribution of DNA internalized through calcium-phosphate precipitation. Exp Cell Res. 1990; 2(190): 170-174

241. Loyter A, Scangos G, Juricek D, Keene D, Ruddle FH. Mechanisms of DNA entry into mammalian cells. II. Phagocytosis of calcium phosphate DNA co-precipitate visualized by electron microscopy. Exp Cell Res. 1982; 1(139): 223-234.

242. Zauner W, Farrow NA, Haines A. In vitro uptake of polystyrene microspheres: effect of particle size, cell line and cell density. J Control Release. 2001; 1(71): 39-51.

243. Tang J, Chen JY, Liu J, Luo M, Wang YJ, Wei XW, Gao X, Wang BL, Liu YB, Yi $\mathrm{T}$, Tong $\mathrm{AP}$, Song XR, Xie YM, Zhao YL, Xiang ML, Huang Y, Zheng Y. Calcium phosphate embedded PLGA nanoparticles: a promising gene delivery vector with high gene loading and transfection efficiency. Int J Pharm. 2012; 431(1-2): 210-221.

244. Shau MD, Shih MF, Lin CC, Chuang IC, Hung WC, Hennink WE, Cherng JY. A one-step process in preparation of cationic nanoparticles with poly(lactide-co-glycolide)-containing polyethylenimine gives efficient gene delivery. Eur J Pharm Sci. 2012; 5(46): 522-529.

245. Zeng $\mathrm{P}$, $\mathrm{Xu} \mathrm{Y}$, Zeng $\mathrm{CH}$, Ren $\mathrm{H}$, Peng ML. Chitosan-modified poly(d,l-lactide-co-glycolide) nanospheres for plasmid DNA delivery and HBV gene-silencing. Int J Pharm. 2011; 415(1-2): 259-266.

246. Ramsay E, Gumbleton M. Polylysine and polyornithine gene transfer complexes: a study of complex stability and cellular uptake as a basis for their differential in-vitro transfection efficiency. J Drug Target. 2002; 1(10): 1-9.

247. Balicki D, Putnam CD, Scaria PV, Beutler E. Structure and function correlation in histone H2A peptide-mediated gene transfer. Proc Natl Acad Sci U S A. 2002; 11(99): 7467-7471.

248. Park YJ, Liang JF, Ko KS, Kim SW, Yang VC. Low molecular weight protamine as an efficient and nontoxic gene carrier: in vitro study. J Gene Med. 2003; 8(5): 700-711.

249. Wang J, Mao HQ, Leong KW. A novel biodegradable gene carrier based on polyphosphoester. J Am Chem Soc. 2001; 38(123): 9480-9481.

250. Ping Y, Wu D, Kumar JN, Cheng W, Lay CL, Liu Y. Redox-responsive hyperbranched poly(amido amine)s with tertiary amino cores for gene delivery. Biomacromolecules. 2013; 6(14): 2083-2094

251. Wu GY, Wu CH. Receptor-mediated in vitro gene transformation by a soluble DNA carrier system. J Biol Chem. 1987; 10(262): 4429-4432.

252. Wagner E, Cotten M, Foisner R, Birnstiel ML. Transferrin-polycation-DNA complexes: the effect of polycations on the structure of the complex and DNA delivery to cells. Proc Natl Acad Sci U S A. 1991; 10(88): 4255-4259.

253. Emmrich S, Wang W, John K, Li W, Putzer BM. Antisense gapmers selectively suppress individual oncogenic p73 splice isoforms and inhibit tumor growth in vivo. Mol Cancer. 2009; 8: 61

254. Thiersch M, Rimann M, Panagiotopoulou V, Öztürk E, Biedermann T, Textor $\mathrm{M}$, Lühmann TC, Hall H. The angiogenic response to PLL-g-PEG-mediated HIF-1a plasmid DNA delivery in healthy and diabetic rats. Biomaterials. 2013; 34(16): 4173-4182.
255. Asparuhova MB, Barde I, Trono D, Schranz K, Schumperli D. Development and characterization of a triple combination gene therapy vector inhibiting HIV-1 multiplication. J Gene Med. 2008; 10(10): 1059-1070.

256. Deng J, Gao N, Wang Y, Yi H, Fang S, Ma Y, Cai L. Self-assembled cationic micelles based on PEG-PLL-PLLeu hybrid polypeptides as highly effective gene vectors. Biomacromolecules. 2012; 13(11): 3795-3804.

257. Morille M, Passirani C, Vonarbourg A, Clavreul A, Benoit JP. Progress in developing cationic vectors for non-viral systemic gene therapy against cancer. Biomaterials. 2008; 29(24-25): 3477-3496.

258. Cutroneo KR. Gene therapy for tissue regeneration. J Cell Biochem. 2003; 2(88): 418-425.

259. Wagner E, Zenke M, Cotten M, Beug H, Birnstiel ML. Transferrin-polycation conjugates as carriers for DNA uptake into cells. Proc Natl Acad Sci U S A. 1990; 9(87): 3410-3414.

260. Mislick KA, Baldeschwieler JD, Kayyem JF, Meade TJ. Transfection of folate-polylysine DNA complexes: evidence for lysosomal delivery. Bioconjug Chem. 1995; 5(6): 512-515.

261. Schachtschabel U, Pavlinkova G, Lou D, Kohler H. Antibody-mediated gene delivery for B-cell lymphoma in vitro. Cancer Gene Ther. 1996; 6(3): 365-372.

262. Sosnowski BA, Gonzalez AM, Chandler LA, Buechler YJ, Pierce GF, Baird A. Targeting DNA to cells with basic fibroblast growth factor (FGF2). J Biol Chem. 1996; 52(271): 33647-33653

263. Samson SL, Gonzalez EV, Yechoor V, Bajaj M, Oka K, Chan L. Gene therapy for diabetes: metabolic effects of helper-dependent adenoviral exendin 4 expression in a diet-induced obesity mouse model. Mol Ther. 2008; 11(16): 1805-1812.

264. Capowski EE, Schneider BL, Ebert AD, Seehus CR, Szulc J, Zufferey R, Aebischer P, Svendsen $\mathrm{CN}$. Lentiviral vector-mediated genetic modification of human neural progenitor cells for ex vivo gene therapy. J Neurosci Methods. 2007; 2(163): 338-349.

265. Okumura K, Nakase M, Nakamura S, Kamei T, Inui M, Tagawa T. Bax gene therapy for human osteosarcoma using cationic liposomes in vivo. Oncol Rep. 2007; 4(17): 769-773.

266. Yoo H, Moon SK, Hwang T, Kim YS, Kim JH, Choi SW, Kim JH. Multifunctional magnetic nanoparticles modified with polyethylenimine and folic acid for biomedical theranostics. Langmuir. 2013; 29(20): 5962-5967.

267. Kono K, Ikeda R, Tsukamoto K, Yuba E, Kojima C, Harada A. Polyamidoamine dendron-bearing lipids as a nonviral vector: influence of dendron generation. Bioconjug Chem. 2012; 4(23): 871-879.

268. Zhou C, Yu B, Yang X, Huo T, Lee LJ, Barth RF, Lee RJ. Lipid-coated nano-calcium-phosphate (LNCP) for gene delivery. Int J Pharm. 2010; 392(1-2): 201-208.

269. Jiang M, Gan L, Zhu C, Dong Y, Liu J, Gan Y. Cationic core-shell liponanoparticles for ocular gene delivery. Biomaterials. 2012; 30(33): 7621-7630.

270. Vu L, Ramos J, Potta T, Rege K. Generation of a focused poly(amino ether) library: polymer-mediated transgene delivery and gold-nanorod based theranostic systems. Theranostics. 2012; 2(12): 1160-1173.

271. Luk BT, Fang RH, Zhang L. Lipid- and polymer-based nanostructures for cancer theranostics. Theranostics. 2012; 2(12): 1117-1126.

272. Guo Y, Liu X, Sun X, Zhang Q, Gong T, Zhang Z. Mannosylated lipid nano-emulsions loaded with lycorine-oleic acid ionic complex for tumor cell-specific delivery. Theranostics. 2012; 2(11): 1104-1114.

273. Yaghoubi SS, Campbell DO, Radu CG, Czernin J. Positron emission tomography reporter genes and reporter probes: gene and cell therapy applications. Theranostics. 2012; 2(4): 374-391.

274. Zhang L, Gu FX, Chan JM, Wang AZ, Langer RS, Farokhzad OC. Nanoparticles in medicine: Therapeutic applications and developments. Clin Pharm Ther. 2008; 83: 761-769.

275. Sokolova V, Epple M. Inorganic nanoparticles as carriers of nucleic acids into cells. Angew Chem Int Ed Engl. 2008; 8(47): 1382-1395.

276. Hafeli UO, Riffle JS, Harris-Shekhawat L, Carmichael-Baranauskas A, Mark F, Dailey JP, Bardenstein D. Cell uptake and in vitro toxicity of magnetic nanoparticles suitable for drug delivery. Mol Pharm. 2009; 5(6): 1417-1428.

277. Panje CM, Wang DS, Pysz MA, Paulmurugan R, Ren Y, Tranquart F, Tian L, Willmann JK. Ultrasound-mediated gene delivery with cationic versus neutral microbubbles: effect of DNA and microbubble dose on in vivo transfection efficiency. Theranostics. 2012; 2(11): 1078-1091.

278. Kittler S, Greulich C, Diendorf J, Koller M, Epple M. Toxicity of silver nanoparticles increases during storage because of slow dissolution under release of silver ions. Chem Mater. 2010; 16(22): 4548-4554.

279. Wang C, Cheng L, Liu Z. Upconversion nanoparticles for photodynamic therapy and other cancer therapeutics. Theranostics. 2013; 3(5): 317-330.

280. Neumann S, Kovtun A, Dietzel ID, Epple M, Heumann R. The use of size-defined DNA-functionalized calcium phosphate nanoparticles to minimise intracellular calcium disturbance during transfection. Biomaterials. 2009; 35(30): 6794-6802.

281. Kubinova S, Sykova E. Nanotechnologies in regenerative medicine. Minim Invasive Ther Allied Technol. 2010; 3(19): 144-156.

282. Raffa V, Vittorio O, Riggio C, Cuschieri A. Progress in nanotechnology for healthcare. Minim Invasive Ther Allied Technol. 2010; 3(19): 127-135. 